\title{
Net primary productivity, allocation pattern and carbon use efficiency in an apple orchard assessed by integrating eddy covariance, biometric and continuous soil chamber measurements
}

\author{
D. Zanotelli ${ }^{1}$, L. Montagnani ${ }^{1,2}$, G. Manca ${ }^{3}$, and M. Tagliavini ${ }^{1}$ \\ ${ }^{1}$ Faculty of Science and Technology, Free University of Bolzano-Bozen, Bolzano, Italy \\ ${ }^{2}$ Forest Services, Autonomous Province of Bolzano-Bozen, Bolzano, Italy \\ ${ }^{3}$ Air and Climate Unit, Institute for Environment and Sustainability, Joint Research Centre of European Commission, \\ Ispra, Italy \\ Correspondence to: D. Zanotelli (damiano.zanotelli@unibz.it)
}

Received: 11 September 2012 - Published in Biogeosciences Discuss.: 15 October 2012

Revised: 5 April 2013 - Accepted: 5 April 2013 - Published: 7 May 2013

\begin{abstract}
Carbon use efficiency (CUE), the ratio of net primary production (NPP) over gross primary production (GPP), is a functional parameter that could possibly link the current increasingly accurate global GPP estimates with those of net ecosystem exchange, for which global predictors are still unavailable. Nevertheless, CUE estimates are actually available for only a few ecosystem types, while information regarding agro-ecosystems is scarce, in spite of the simplified spatial structure of these ecosystems that facilitates studies on allocation patterns and temporal growth dynamics.

We combined three largely deployed methods, eddy covariance, soil respiration and biometric measurements, to assess monthly values of CUE, NPP and allocation patterns in different plant organs in an apple orchard during a complete year (2010). We applied a measurement protocol optimized for quantifying monthly values of carbon fluxes in this ecosystem type, which allows for a cross check between estimates obtained from different methods. We also attributed NPP components to standing biomass increments, detritus cycle feeding and lateral exports.

We found that in the apple orchard, both net ecosystem production and gross primary production on a yearly basis, $380 \pm 30 \mathrm{~g} \mathrm{C} \mathrm{m}^{-2}$ and $1263 \pm 189 \mathrm{~g} \mathrm{C} \mathrm{m}^{-2}$ respectively, were of a magnitude comparable to those of natural forests growing in similar climate conditions. The largest differences with respect to forests are in the allocation pattern and in the fate of produced biomass. The carbon sequestered from the
\end{abstract}

atmosphere was largely allocated to production of fruit: $49 \%$ of annual NPP was taken away from the ecosystem through apple production. Organic material (leaves, fine root litter, pruned wood and early fruit falls) contributing to the detritus cycle was $46 \%$ of the NPP. Only $5 \%$ was attributable to standing biomass increment, while this NPP component is generally the largest in forests.

The CUE, with an annual average of $0.71 \pm 0.12$, was higher than the previously suggested constant values of $0.47-0.50$. Low nitrogen investment in fruit, the limited root apparatus, and the optimal growth temperature and nutritional condition observed at the site are suggested to be explanatory variables for the high CUE observed.

\section{Introduction}

Global greenhouse gases (GHGs) concentration in atmosphere has been growing since preindustrial times due to anthropogenic forcing, in particular fossil fuel combustion and land use change (Canadell et al., 2007; Le Quèrè et al., 2009), with carbon dioxide $\left(\mathrm{CO}_{2}\right)$ being the prevalent anthropogenic GHG (IPCC-AR4, 2007; Peters et al., 2011). By sequestering a large amount of atmospheric carbon (C), terrestrial ecosystems are thought to offer a mitigation strategy for reducing global warming (Schimel et al., 2001). This is confirmed by the observation that the annual increment of atmospheric $\mathrm{CO}_{2}$ is substantially smaller than the increment in 
anthropogenic emissions and, on a global scale, it has been estimated that the terrestrial biosphere is able to take up about $30 \%$ of anthropogenic $\mathrm{CO}_{2}$ emissions annually (Schulze, 2006; Canadell et al., 2007).

Several studies have been carried out to assess the capacity of ecosystems in different natural biomes to sequester $\mathrm{C}$ from the atmosphere, most of which related to FLUXNET synthesis activity (Baldocchi, 2008; http://www.fluxnet.ornl.gov/) and results have been recently reviewed in a global dataset (Luyssaert et al., 2007; Schulze et al., 2010).

While extensive knowledge on natural ecosystem is available, the carbon sequestration potential of intensively managed ecosystems, particularly woody agro-ecosystems, have been poorly studied, although some crop classes may assume great importance especially at regional scale (Testi et al., 2008). Agricultural practices such as soil tillage, fertilization, irrigation, pruning and the reduced biodiversity occurring in agricultural systems may significantly alter their capacity to exchange $\mathrm{C}$ with the atmosphere (Smith, 2004; Osborne et al., 2010) and thus their potential to act as a sink of $\mathrm{C}$ as compared to natural ecosystems growing in similar environmental conditions.

Woody agro-ecosystems are among the least quantified and most uncertain elements in the terrestrial biogeochemical cycle. In the present study we hypothesize that the main ecosystem carbon fluxes of a woody agro-ecosystem are of the same magnitudes with respect to those of a natural forested ecosystem of the same biome rank (temperatehumid deciduous forest), while the main differences between the two land use types take place in the allocation pattern of fixed C.

An effective way to compare the ability of different ecosystems to sequester $\mathrm{CO}_{2}$ from the atmosphere is to determine their carbon use efficiency (CUE). CUE is an intuitive and easily comparable index to assess the capacity of an ecosystem to transfer $\mathrm{C}$ from the atmosphere to terrestrial biomass (De Lucia et al., 2007).

CUE is the ratio between net primary production (NPP) and gross primary production (GPP):

$\mathrm{CUE}=\frac{\mathrm{NPP}}{\mathrm{GPP}}$.

Values of NPP and GPP can be derived as follows:

$\mathrm{NPP}=\mathrm{GPP}-R_{\mathrm{a}}=\mathrm{NEP}+R_{\mathrm{h}}$

and

$\mathrm{GPP}=\mathrm{NPP}+R_{\mathrm{a}}=\mathrm{NEP}+R_{\mathrm{eco}}$,

where NEP is the net ecosystem production and $R_{\text {eco }}$ is the ecosystem respiration given by autotrophic respiration $\left(R_{\mathrm{a}}\right)+$ heterotrophic respiration $\left(R_{\mathrm{h}}\right)$.

Estimates of GPP, both derived from flux networks (Beer et al., 2010) and from satellite observations (Peng et al., 2013), are increasingly robust, while reliable climatic and biological predictors of NEP are still unavailable at global scale. Increasing our knowledge on the magnitude and spatial distribution of CUE and $R_{\mathrm{h}}$ could allow a better linkage of the GPP estimates with those of NPP and NEP.

We investigated an apple orchard (Malus domestica Borkh.) growing in the temperate-humid area of South Tyrol, Italy, and compared it with data taken from literature of temperate-humid forests (Curtis et al., 2002; Luyssaert et al., 2007; DeLucia et al., 2007). The crop class considered is globally relevant, being cultivated worldwide over 4.75 million hectares (FAOSTAT, 2010). We used CUE as a comparison index and we biometrically measured the NPP of the main ecosystem compartments to assess the $\mathrm{C}$ allocation pattern in the year 2010. In order to test the robustness of the measurements of $\mathrm{C}$ fluxes involved in CUE determination (GPP, NPP and $R_{\mathrm{a}}$ ), we adopted an experimental protocol that allowed us to obtain a cross check between independent estimates of each flux.

Given the relevance of CUE estimates and the paucity of existing reliable values for different ecosystem types and climates, we addressed as a main question in this study if current methodologies used to quantify $\mathrm{C}$ stocks and fluxes can be combined to robustly quantify the CUE in a woody agroecosystem chosen as an exemplary model.

\section{Materials and methods}

\subsection{Site description}

The study site is located in the intensively cultivated valley bottom of the Adige River, in the municipality of Caldaro, South Tyrol, Italy $\left(46^{\circ} 21^{\prime} \mathrm{N}, 11^{\circ} 16^{\prime} \mathrm{E} ; 240 \mathrm{~m}\right.$ a.s.l.). Apple trees (Malus domestica Borkh., variety Fuji grafted on dwarfing EMLA 9 rootstock) were planted in rows in the year 2000, following a regular frame of $3 \times 1 \mathrm{~m}$, where $1 \mathrm{~m}$ is the distance between plants along the row and $3 \mathrm{~m}$ is the distance between tree rows. The average pruned tree height was $3.6 \mathrm{~m}$. A $1.2 \mathrm{~m}$ wide strip of soil centered on the tree row was kept free of grass through periodic tillage. In the $1.8 \mathrm{~m}$ wide alleys between tree rows, grasses were free to grow and were cut 3 times during the year. Apple tree plantations with the same characteristics were present around the selected field for a minimum distance of $300 \mathrm{~m}$ in all directions.

Budburst occurred in the second half of March, trees maximum LAI was $2.8 \mathrm{~m}^{2} \mathrm{~m}^{-2}$ in July and major leaf fall started at the end of October. The $30 \mathrm{yr}$ average mean annual temperature was $11.5^{\circ} \mathrm{C}$, while the mean annual temperature during 2010 was $11.6^{\circ} \mathrm{C}$. Total water input for 2010 was $1370 \mathrm{~mm}$, of which $1050 \mathrm{~mm}$ came from precipitation and $320 \mathrm{~mm}$ from irrigation. The soil is a Calcaric Cambisol according to the FAO Soil Taxonomy, with a $\mathrm{pH}$ of 7.4. In the upper $20 \mathrm{~cm}$ the soil bulk density was 1.49 , the organic carbon concentration was $1.74 \%$ and the nitrogen concentration was $0.20 \%$. The orchard was managed according to the 
guidelines of organic farming. Organic fertilizers were applied in a single rate in March 2010, providing $35.5 \mathrm{~g} \mathrm{C} \mathrm{m}^{-2}$ and $7.5 \mathrm{~g} \mathrm{~N} \mathrm{~m}^{-2}$. Fruit yield in the period 2009-2012 ranged between 45.2 and $74.4 \mathrm{tha}^{-1}$.

\subsection{Experimental setup}

The site was selected based on the favorable conditions for eddy covariance (EC) measurement in terms of regular terrain and homogeneity of land surface cover. An $8 \mathrm{~m}$ tower was set up at the beginning of 2009. Instruments for EC measurements were installed at the top of this tower. Additionally, the tower was equipped with a series of meteorological instruments. Solar radiation components were measured by CNR1, Kipp \& Zonen, Delft, Holland; air temperature and relative humidity by CS215, Campbell Scientific Incorporated, Logan, Utah, United States (CSI hereafter); rainfall by a professional rain gauge (RAIN-O-MATIC, Pronamic, Silkeborg, Denmark), and soil water content by multiple TDRs (CS616, CSI). All meteorological data were collected by a CR3000 (CSI) datalogger.

Close to the tower, 16 collars $(20 \mathrm{~cm}$ diameter) for soil respiration measurement were placed along a selected row at $35-55 \mathrm{~cm}$ from the trees, 8 on control plots and 8 on trenching plots. Soil trenching $(50 \times 50 \times 60 \mathrm{~cm})$ was carried out in summer 2009. Practical limitations for expanding the survey area to other treelines and grassed alleys were encountered since the measurement chambers would have been an obstacle to the farm machinery. This limitation was overcome by carrying out a parallel independent campaign for assessing the spatial variability of soil respiration in the field.

After a characterization of tree diameters that was conducted over the whole site, six groups of five plants each were selected in order to represent the probability density distribution of the observed tree diameter. Nets for litter collection were placed under selected trees and biometric measurements were carried out during the 2010 growing season to assess the total NPP and carbon allocation within the studied ecosystem. Along with measurements and litter collection, 9 branches ( 3 per plant level) were cut from randomly selected trees and brought to the laboratory for analysis at each sampling date. The collected material was used to determine the mean dry weight of each organ (after drying in oven to a constant weight at $65^{\circ} \mathrm{C}$ ), the mean carbon and nitrogen content of each NPP component (FlashEA ${ }^{\mathrm{TM}} 1112$ Elemental Analyzer, Thermo Fisher Scientific, Germany) and the mean leaf surface (LI-3000 + LI-3050 Portable Area Meters, Li-Cor Biosciences, Lincoln, Nebraska, USA, Li-Cor hereafter).

\subsection{Measurement techniques}

\subsubsection{Eddy covariance measurements}

Net ecosystem exchange (NEE) of $\mathrm{CO}_{2}$ has been measured continuously by the eddy covariance technique since March 2009. Measurements and calculation were performed following the Euroflux methodology as described by Aubinet et al. (2000) with a 3-D sonic anemometer (Gill R3-50, Gill Instruments, Lymington, UK) at a height of $8 \mathrm{~m}$ aboveground ( $4 \mathrm{~m}$ above the canopy) and a close path $\mathrm{CO}_{2} / \mathrm{H}_{2} \mathrm{O}$ infrared gas analyzer (IRGA, LI-7000, Li-Cor). Air was sampled through a polyethylene tube $(4 \mathrm{~mm}$ inner, $6 \mathrm{~mm}$ external diameter and a length of $12 \mathrm{~m}$ ) at a distance of $0.3 \mathrm{~m}$ from the anemometer with a flux rate of $10 \mathrm{~L} \mathrm{~min}^{-1}$ provided by an external pump (N838 KNDC, KNF Neuberger GmbH, Freiburg, Germany). Calibration was performed bi-weekly with reference gases: nitrogen and $380 \mathrm{ppm} \mathrm{CO}_{2}$ flasks (produced by Messer, Grugliasco, Italy) were used to set the zero and the $\mathrm{CO}_{2}$ span, respectively. Zero level of $\mathrm{CO}_{2}$ and $\mathrm{H}_{2} \mathrm{O}$ in the reference cell of the analyzer was assured by the use of chemicals (respectively Ascarite II for $\mathrm{CO}_{2}$ and magnesium perchlorate for water vapor), which were substituted biweekly. The software Eddysoft (Kolle and Rebmann, 2007; Mauder et al., 2008) was used to calculate eddy fluxes with the following criteria: no detrending, no high- or low-pass filtering corrections were used; a two-axis rotation of coordinates was applied each $30 \mathrm{~min}$. The Eddysoft software uses the algorithm proposed by Eugster and Senn (1995) to correct for the underestimation of covariance signal due to damping of high-frequency fluctuation of $\mathrm{CO}_{2}$ concentration. The high-frequency loss was estimated comparing the cospectra of the virtual heat flux, which we assume free of high-frequency damping, with the cospectra of the turbulent $\mathrm{CO}_{2}$ flux. The software automatically calculated the lag time for $\mathrm{CO}_{2}$ at each half hour to maximize the covariance between fluctuations in vertical wind velocity and gas molar fraction. In addition, the analysis of stationarity conditions for $\mathrm{CO}_{2}$ turbulent flux and of the integral turbulent characteristics (ITC) following Foken and Wichura (1996) was performed.

Gaps in data collection, which represented $7.2 \%$ of the yearly half hours, and $\mathrm{CO}_{2}$ flux values removed due to quality control concern, were filled with look-up tables (LUT) based on meteorological seasonal conditions. Two different tables were compiled: one for nighttime and one for daytime. For both tables only quality checked data were used as input. Average fluxes for the nighttime table were calculated using a moving bi-monthly LUT with 15 day sliding window, compiled for 21 classes of relative soil water content and 26 classes of air temperature. The ranging interval of a meteorological variable in a specific class depended on the ratio between the overall range of the variable in the bi-monthly period and the number of classes. Gaps in the fifteen central days of the LUT were filled and then the temporal window 
of the LUT was moved 15 days ahead. For the daytime the bi-monthly moving LUT with a 15 days sliding window was compiled for 26 classes of air temperature and 26 classes of global radiation $(\mathrm{Rg})$. $\mathrm{Rg}$ was also used to distinguish day from night $\left(\mathrm{Rg}>20 \mathrm{~W} \mathrm{~m}^{-2}\right)$.

The partitioning of the observed NEE into GPP and $R_{\text {eco }}$ was achieved through nighttime LUT used for gap filling. Indeed, daytime $R_{\text {eco }}$ values for a bi-monthly period were extrapolated from the nocturnal LUT according to air temperature and soil humidity for the specific daytime half-hour period.

As a form of control, gap filling was also performed by the marginal distribution sampling method, which accounts for temporal autocorrelation of fluxes, replacing missing data with the average value under similar meteorological conditions (Reichstein et al., 2005) and by the light response curve approach described by Lasslop et al. (2010), using the online standard tool (http://www.bgc-jena.mpg.de/bgc-mdi/ html/eddyproc/index.html). GPP and $R_{\text {eco }}$ calculation was performed using the same tool.

\subsubsection{Biometric measurements}

Biometric measurements were conducted over six representative plots following Law et al. (2008), which led us to set up a correct field plot design and consider all the relevant elements to be monitored. Six NPP components were considered separately: leaves (NPPl); fruit (NPP $f$ ); aboveground woody tissues ( $\mathrm{NPP} w_{\mathrm{AG}}$ ), which include trunks, branches and shoots; belowground woody tissues ( $\mathrm{NPP} w_{\mathrm{BG}}$ ), which include coarse roots and the belowground part of trunk; fine roots (NPP $f r)$; understory production (NPP $u$ ). Each of these fluxes was assessed directly and independently. We did not consider root exudate production in this budget, which for apple trees growing in similar soil types can represent up to $30 \%$ of fine root production (Scandellari et al., 2007), non$\mathrm{CO}_{2}$ carbon emission and the volatile organic compounds (VOC), whose contribution to total NPP is assumed to be negligible (Arneth et al., 2011; Malhi et al., 2009). Biological samples, leaf and fruit numbers, trunk circumference values and root images were taken once a month. The following general equation was used to calculate the NPP between two consecutive sampling dates:

$\mathrm{NPP}=L_{t+1}+\mathrm{Sb}_{t+1}-\mathrm{Sb}_{t}$,

where $L$ is the litter collected from the nets and $\mathrm{Sb}$ is the standing biomass. Using this procedure, shrinkage effects in tree diameter may determine apparent reduction in wood biomass. Variations in $\mathrm{C}$ storage within tree organs along the vegetative season were not considered beside their relevance (Cannell and Dewar, 1994). When $L$ was negligible, Eq. (4) was simplified as follows:

$\mathrm{NPP}=\mathrm{Sb}_{t+1}-\mathrm{Sb}_{t}$.
Details on the sampling procedures for each NPP component are described below.

$\mathrm{NPPl}$ - one tree out of each plot for a total of 6 trees was selected. In April 2010 we divided the trees according to 3 height levels (low $=0-120 \mathrm{~cm}$, medium $=120-240 \mathrm{~cm}$, high $=240-360 \mathrm{~cm}$ ) to represent vertical variability within the trees (e.g., Rayment et al., 2002). We also numbered and tagged all the branches and we counted the number of leaves and flowers on each branch.

Three branches per tree level were then chosen, and from May till November the number of leaves and fruit of these 9 branches per tree were monitored, avoiding any sampling collection. We used the complete characterization carried out in April to determine a multiplicative factor, specific to each plant level, to upscale measured values to the whole tree. The derived total number of leaves per tree was multiplied by the mean dry weight of leaves of that period, and thus by leaf carbon concentration, to determine the total amount of $\mathrm{C}$ in the leaves.

The mean leaf area was determined by measuring the leaf surface of the sampled material by LI-3000 + LI-3050 (LiCor). The leaf area index (LAI) of the trees was obtained by taking into account the mean leaf area, the total number of leaves and the soil surface $\left(3 \mathrm{~m}^{2}\right)$ occupied by each tree.

Leaf abscission was monitored by collecting the litter from nets placed under each selected plot on the same sampling date. NPP $l$ was thus calculated using Eq. (4).

$\mathrm{NPP} f$ - once a month, flowers (April) and fruit (from May till October) were counted on the selected branches. The total number of fruit per plant was counted at harvest (October) and a multiplicative factor was used to extrapolate fruit number reduction due to early drop from selected branches to the whole tree, thus obtaining an estimate of total number of fruit per tree throughout the season. In a similar way as for the leaves, in order to assess $\mathrm{C}$ allocation to fruit, the total number of fruit was multiplied by their mean dry weight at each sampling date and by the mean $C$ content. Equation (4) was applied to assess NPPf.

$\mathrm{NPP} w_{\mathrm{AG}}-\mathrm{NPP} w_{\mathrm{AG}}$ was assessed as the difference between values of $A G$ woody standing biomass $\left(\operatorname{wood}_{\mathrm{AG}}\right) \mathrm{cal}-$ culated over time (Eq. 5). wood $_{\mathrm{AG}}$ was modeled based on measured tree circumferences at $10 \mathrm{~cm}$ above grafting points for each selected tree $(n=30)$. The allometric equation used to determine it was

$\operatorname{wood}_{\mathrm{AG}}=a x^{b}$,

where $x$ is the diameter at $10 \mathrm{~cm}$ above the grafting point, $a$ and $b$ are parameters of the appropriate power equation (Table 1).

Allometric equation parameters were determined by excavating 11 apple trees of the same age and size, grown in similar environmental and soil conditions in a nearby orchard. Since apple trees are pruned each year during winter, the same plant diameter may lead to a significant difference in aboveground (AG) woody biomass estimate, depending on 


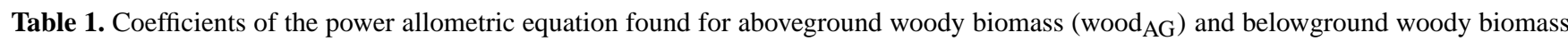

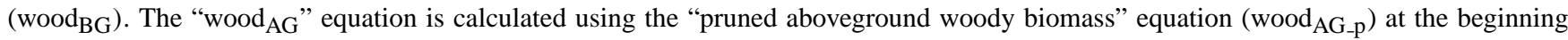
of the season and the "not-pruned aboveground woody biomass" equation at the end of the season (wood AG_np), thus accounting for the pruning material. Reported are parameters with their relative standard errors.

\begin{tabular}{lrrrrr}
\hline Woody organs & $n$ & Intercept \pm se & Exponent \pm se & $R^{2}$ & $p$ value \\
\hline wood $_{\text {AG_np }}$ & 11 & $229.3158 \pm 1.3820$ & $1.6115 \pm 0.1787$ & 0.9105 & $<0.001$ \\
wood $_{\text {AG_p }}$ & 11 & $202.9379 \pm 1.3682$ & $1.6115 \pm 0.1787$ & 0.9105 & $<0.001$ \\
wood $_{\text {AG }}$ & 2 & $0.0384 \pm$ na & $6.2470 \pm$ na & na & na \\
wood $_{\text {BG }}$ & 11 & $46.7026 \pm 1.9599$ & $1.7694 \pm 0.3716$ & 0.7391 & 0.0014 \\
\hline
\end{tabular}

whether allometric equations are applied to pruned or unpruned trees. To consider this effect, we built a first allometric equation with pruned trees $\left(\operatorname{wood}_{\mathrm{AG}_{\mathrm{p}} \mathrm{p}}\right)$ and a second equation with unpruned trees ( $\operatorname{wood}_{\mathrm{AG} \_n p}$; see respective parameters in Table 1). Based on our measurements, pruning material was quantified in $11.5 \%$ of AG woody biomass. To calculate the $\operatorname{wood}_{\mathrm{AG}}$ at monthly time steps, a third allometric equation (see Table 1 for equation parameters) was determined with an initial value (April) on the ordinate set by the equation for pruned trees and the final value (November) on the ordinate set by equation for unpruned trees.

$\mathrm{NPP} w_{\mathrm{BG}}$ - the belowground (BG) standing biomass present within a radius of $15 \mathrm{~cm}$ around the tree stem, to a vertical depth of $1 \mathrm{~m}$, was determined during the excavation of the trees used for NPP $w_{\mathrm{AG}}$, This value was integrated in space by considering the coarse roots excavated through soil coring (see below). Coarse roots were considered if they measured $>2 \mathrm{~mm}$ in diameter. Spatial interpolation was performed by ordinary kriging, assuming a maximum root depth of $1 \mathrm{~m}$. A power allometric equation was established to relate tree diameter and belowground woody organs $\left(\operatorname{wood}_{\mathrm{BG}}\right)$.

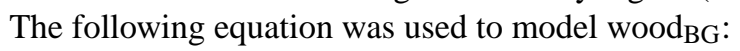

$\operatorname{wood}_{\mathrm{BG}}=c x^{d}$,

where $x$ is the diameter at $10 \mathrm{~cm}$ above the grafting point and $c$ and $d$ are the parameters of the best fitting power equation reported in Table 1. We assumed that all coarse root growth accounted for standing biomass increase, so not contributing to detritus cycle. We therefore used Eq. (5) to determine $\mathrm{NPP} w_{\mathrm{BG}}$.

NPP $f r$ - in March 2010, an intensive soil sampling campaign was carried out in order to assess the mean root biomass and its distribution. One tree per plot was selected and 17 soil cores were taken at each of the six plots, along two parallel lines across tree rows at different distances $(>15 \mathrm{~cm})$ from the tree trunks. Each soil core was divided into 3 depth levels: 0-20, 20-40 and 40-60 cm. Each soil sample $(n=306)$ was sieved to extract roots, separating them into coarse (diameter $>2 \mathrm{~mm}$ ) and fine $(<2 \mathrm{~mm})$ roots. Interpolation in space of fine root density values was performed as for coarse roots.
In summer 2009, several minirhizotrons were installed in the apple orchard, at distances of $15,35,55$ and $150 \mathrm{~cm}$ from the tree. They consisted of transparent Plexiglas tubes $(8 \mathrm{~cm}$ diameter, $1 \mathrm{~m}$ length) inserted into the soil on an angle of $45^{\circ}$ for approximately $90 \mathrm{~cm}$, thus exploring a soil depth of $60 \mathrm{~cm}$. Starting from 18 March 2010, root growth was monitored by collecting periodic images inside the minirhizotrons using a root scanner (CI-600 Root Scanner, CID-Inc, Camas, WA, USA). After a first screening of the collected images, 8 representative minirhizotrons were considered for the analysis. To assess fine root NPP, their relative growth rate was calculated by image analysis (WinRHIZO software, Regent Instruments, Canada). Since it was difficult to ascertain if brown, old roots were still alive, tracks of the newly formed white roots were added to those already present in the elaborated images. In such a way, the amount of fine roots derived from image analysis represented a virtual $\mathrm{Sb}$ given by the sum of roots already present in March $\left(t_{0}\right)$ and those produced during that year. From the ratio between successive values of virtual standing biomass and the one determined at $t_{0}$, we obtained the relative growth rate, which was applied to the value of initial fine root biomass assessed by soil coring. NPP $f r$ was determined as the difference of Sb values assessed over time (Eq. 5). No distinction was made between the growth pattern of grass and tree roots.

To estimate the amount of fine root production feeding the detritus cycle, we assumed a constant ratio between the standing biomass of fine and coarse roots in the dormant season and that the excess in fine root production was annually shed.

NPP $u$ - NPP of the understory was assessed on the basis of the biomass mowed in the grassed alley: close to the monitored trees, 6 control plots of $1.8 \mathrm{~m}^{2}$ were selected and mowed on a monthly basis. Grass root growth, observed with minirhizotrons, was considered as an NPP $f r$ component. The herbaceous biomass grown along the tree row in periods between tillage events was assumed to be negligible.

\subsubsection{Soil respiration measurements}

An automatic multichambered $\mathrm{CO}_{2}$ soil flux measurement system (LI-8100 + LI-8150 with 8 chambers type LI-8100104 , Li-Cor) was used to measure soil respiration $\left(R_{\mathrm{S}}\right)$ and 
its heterotrophic component $\left(R_{\mathrm{h}}\right)$ along the tree row. Four chambers were kept on the same collars for the whole season, while the other four were rotated over 12 different positions on a weekly basis. Fluxes in each chamber were taken every half hour. Out of the 16 collars installed as described in Sect. 2.2, eight were on control plots (to assess $R_{\mathrm{S}}$ ) and eight were on trenching plots (to assess $R_{\mathrm{h}}$ ). $\mathrm{CO}_{2}$ concentration values were taken every second for a measurement period of $2 \mathrm{~min}$ and $35 \mathrm{~s}$. The first $45 \mathrm{~s}$ were considered as a mixing period and excluded from the calculation of the soil $\mathrm{CO}_{2}$ efflux, which was obtained from the linear regression of the increasing $\mathrm{CO}_{2}$ concentration within the chamber over $1 \mathrm{~min}$ and $50 \mathrm{~s}$.

Soil respiration measurements with the automated chambers were performed during the snow-free period. Until March, measurements were done at a single location to measure $R_{\mathrm{S}}$. Overall, more than 26000 data points for both $R_{\mathrm{S}}$ and $R_{\mathrm{h}}$ were recorded, and gaps represented $46.2 \%$ for $R_{\mathrm{S}}$ and the $57.1 \%$ for $R_{\mathrm{h}}$ of the annual half hours. As quality control we used the correlation coefficient of the linear relation between time and $\mathrm{CO}_{2}$ concentration, discarding values with $R^{2}$ below 0.95 - a more restrictive threshold than that 0.90 proposed by Savage et al. (2008). Gap filling was performed on data collected at each collar following the LUT method, with air temperature and soil humidity as independent variables. Total $R_{\mathrm{S}}$ and $R_{\mathrm{h}}$ were calculated by summing the gap-filled time series.

A possible source of systematic error occurring with automated system is linked with the limited spatial representativeness of the point of $R_{\mathrm{S}}$ measurement (Savage et al., 2008), imposed by the nature of the system and the logistics of the study site. In order to obtain reliable values of $R_{\mathrm{s}}$, $R_{\mathrm{h}}$, and $R_{\mathrm{a} \_\mathrm{BG}}$ (belowground autotrophic respiration, calculated as $R_{\mathrm{S}}-R_{\mathrm{h}}$ ), for the whole ecosystem, in June 2010 a parallel soil respiration measurement campaign was carried out in order to (1) take into account the spatial variability of soil respiration in the treelines (the soil strips under the tree canopy, $1.2 \mathrm{~m}$ width) and to (2) estimate the soil respiration in the areas corresponding to the grassed alleys $(1.8 \mathrm{~m}$ width). Six collars $(10 \mathrm{~cm}$ diameter) were placed at different distances from the trees ( 5 in the treeline and 1 in the grassed alley) in each plot used for biometric measurements (36 collars in total) and 7 measurement cycles of $R_{\mathrm{S}}$ over one week were performed for each collar by a second LI8100 with a LI-8100-102 survey chamber. The relations of $R_{\mathrm{S}}$ with air temperature observed in the collars located in the treelines and in the grassed alleys during this campaign were used to upscale continuous measurements to the whole orchard. The limited availability of a second analyzer for $R_{\mathrm{S}}$ measurements did not allow us to repeat this parallel survey campaign in other periods of the season. We recommend this operation to be done in order to take properly into account the seasonal differences in the patterns of local and spatial values of $R_{\mathrm{S}}$.

\section{$2.4 R_{\mathrm{a}}$ assessment}

Autotrophic respiration was not measured directly but derived in three ways from measurements that rely on different methodologies. The first method follows the equation

$R_{\mathrm{a}}=\mathrm{GPP}-\mathrm{NPP}$,

where GPP is derived from EC and NPP is assessed biometrically.

The second method follows the equation

$R_{\mathrm{a}}=R_{\mathrm{eco}}-R_{\mathrm{h}}$,

where the first right-hand term is EC derived and the latter is measured with the soil chamber system.

The third method to assess $R_{\mathrm{a}}$ is independent from EC measurements. It is based on the estimate of the autotrophic component of the soil respiration $\left(R_{\mathrm{a}_{-} \mathrm{BG}}=R_{\mathrm{S}}-R_{\mathrm{h}}\right)$ and on the approach suggested by Reich et al. (2006), who observed a consistent near-isometric scaling of total and aboveground plant respiration $\left(R_{\mathrm{a}-\mathrm{AG}}\right)$ to total and aboveground plant $\mathrm{N}$ content across different taxa, environments and experiments. We firstly calculated the amount of $\mathrm{N}$ present in the root biomass of the grassed alleys and in the root biomass of the treelines, then we scaled up $R_{\mathrm{a}-\mathrm{BG}}$ to the whole ecosystem according to the $\mathrm{N}$ distribution in plant organs.

By this method,

$R_{\mathrm{a}}=k\left(R_{\mathrm{a}-\mathrm{BG}}\right)$,

where the coefficient $k$ accounts for the ratio between measured total and belowground $\mathrm{N}$ content (Table 2). This upscaling does not take into account the seasonal variability in above and below standing biomass and $\mathrm{N}$ concentration. Based on the studies of Ceccon et al. (2011) and Akburak et al. (2012), the increase of $\mathrm{N}$ content in roots late in the growing season can partly compensate the parallel increment of $\mathrm{N}$ content in the AG biomass. Additional measurements of $\mathrm{N}$ and $\mathrm{C}$ content along the season would be required to shed light on the internal cycling of these elements and to reduce uncertainties in computation of this scaling factor.

\subsection{NPP, GPP and CUE estimates}

NPP was assessed biometrically ( $\left.\mathrm{NPP}_{\text {biom }}\right)$ by adding the cumulated values of each NPP component considered in the biometric measurements and by summing the yearly NEP and $R_{\mathrm{h}}\left(\mathrm{NPP}_{\text {flux }}\right)$, thus involving eddy covariance and the soil respiration chamber system, respectively. The daily carbon uptake rate was calculated by dividing both the cumulated $\mathrm{NPP}_{\text {biom }}$ and $\mathrm{NPP}_{\text {flux }}$ at each sampling date by the number of days between the current sampling date to the previous one.

GPP was calculated following two methods. The first annual estimate of it $\left(\mathrm{GPP}_{\mathrm{EC}}\right)$ was obtained from flux partitioning of EC-derived NEE fluxes, while the second yearly GPP value $\left(\mathrm{GPP}_{\mathrm{BS}}\right)$ was calculated avoiding any involvement of 
Table 2. Distribution of dry weight (DW), C and N stocks within the ecosystem at the beginning of the growing season (March 2010). wood $_{\mathrm{AG}}$ includes trunks and standing branches of different age; wood $_{\text {BG }}$ represents coarse roots (Table 1). Fine roots were obtained by the intensive soil core sampling conducted in March 2010. Soil $\mathrm{C}$ and $\mathrm{N}$ content in the upper $60 \mathrm{~cm}$ of soil were $21.3 \pm 2.8$ and $2.5 \pm 0.3 \mathrm{~kg} \mathrm{~m}^{-2}$, respectively.

\begin{tabular}{lcc|cc|cc}
\hline $\begin{array}{l}\text { Components } \\
\text { (March 2010) }\end{array}$ & \multicolumn{2}{c|}{ DW } & \multicolumn{2}{c|}{$\mathrm{C}$} & \multicolumn{2}{c}{$\mathrm{N}$} \\
& $\mathrm{kg} \mathrm{m}^{-2}$ & $\%$ & $\mathrm{~kg} \mathrm{~m}^{-2}$ & $\%$ & $\mathrm{~kg} \mathrm{~m}^{-2}$ & $\%$ \\
\hline wood $_{\mathrm{AG}}$ & 1.85 & 72.3 & 0.84 & 72.4 & 0.014 & 65.7 \\
wood $_{\text {BG }}$ & 0.42 & 16.3 & 0.19 & 16.4 & 0.003 & 15.3 \\
Fine roots & 0.29 & 11.4 & 0.13 & 11.2 & 0.004 & 19 \\
\hline Total & 2.56 & 100 & 1.16 & 100 & 0.021 & 100 \\
\hline
\end{tabular}

the eddy covariance methodology by summing $\mathrm{NPP}_{\text {biom }}$ with the $R_{\mathrm{a}}$ assessed using Eq. (10).

To assess the yearly value of CUE, we divided annual values of $\mathrm{NPP}_{\text {biom }}$ and $\mathrm{NPP}_{\text {flux }}$ by both $\mathrm{GPP}_{\mathrm{EC}}$ and $\mathrm{GPP}_{\mathrm{BS}}$, thus obtaining four CUE estimates. Out of these estimates, only the first one $\left(\mathrm{NPP}_{\text {biom }} / \mathrm{GPP}_{\mathrm{EC}}\right)$ is truly independent, while the other three are inherently autocorrelated (Vickers et al., 2009).

The seasonal trend of CUE was assessed in two ways $\left(\mathrm{CUE}_{\text {biom }}\right.$ and $\left.\mathrm{CUE}_{\text {flux }}\right)$ - by dividing the $\mathrm{NPP}_{\text {biom }}$ and $\mathrm{NPP}_{\text {flux }}$ values at each sampling date by the respective $\mathrm{GPP}_{\mathrm{EC}}$ amount.

\subsection{Statistical analysis and uncertainty estimate}

Random and systematic errors affecting biometric, eddy covariance and soil respiration measurements (Clark et al., 2001; Loescher et al., 2006; Savage et al., 2008) contribute to the uncertainty in the estimate of each flux component. The different spatial representativeness of the measurement techniques deployed is an additional source of uncertainty affecting the overall carbon cycle estimate. We evaluated the uncertainty in EC-based fluxes estimates by comparing results from different gap-filling and partitioning methods. Uncertainties (expressed as standard error, se) on $R_{\mathrm{S}}$ and $R_{\mathrm{h}}$ were evaluated from the gap-filled data obtained from the different collars $(n=8)$. These estimates were horizontally scaled based on the ratio between $R_{\mathrm{S}}$ measurements of the multichambered system and those from the spatial survey $(n=210)$. Uncertainties in this ratio as well as in the ratio (k) used to scale up $R_{\mathrm{a} \text { BG }}$ to total $R_{\mathrm{a}}$ were computed following Eqs. (11) and (12).

Additive and multiplicative random errors in biometric estimates were calculated by means of the error propagation theory (Taylor, 1982). When two means $(X$ and $Y$ ) with their standard errors of the mean $\left(\mathrm{SEM}_{x}\right.$ and $\left.\mathrm{SEM}_{y}\right)$ were added yielding the value $Z$, the standard error of $Z\left(\mathrm{SEM}_{z}\right)$ was calculated as follows:

$\operatorname{SEM}_{z}=\sqrt{\left(\operatorname{SEM}_{x}\right)^{2}+\left(\operatorname{SEM}_{y}\right)^{2}}$,

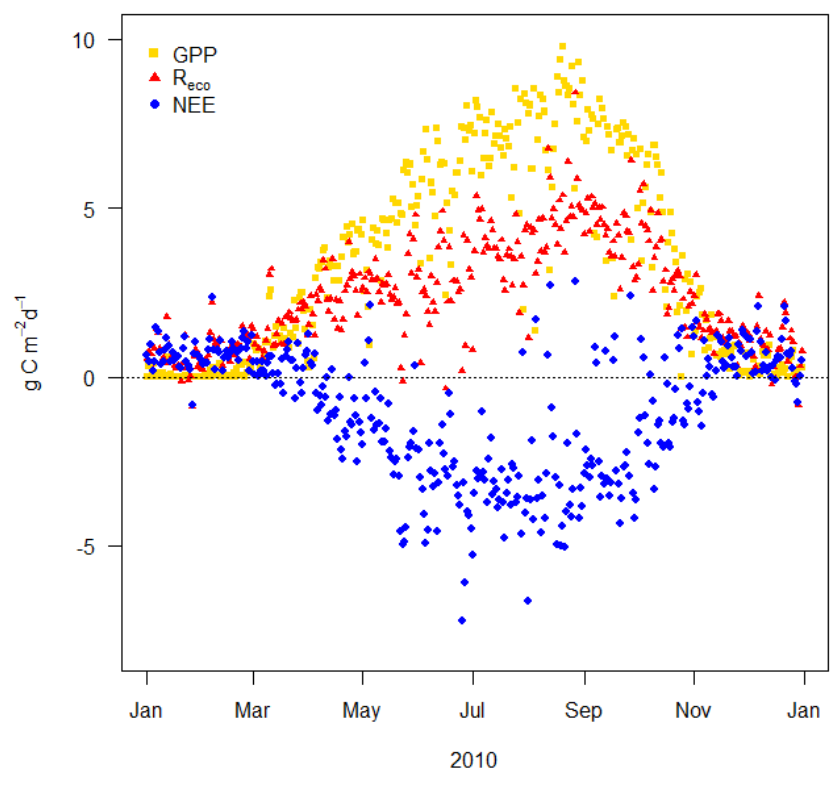

Fig. 1. Eddy covariance measured and derived $\mathrm{C}$ fluxes $\left(\mathrm{g} \mathrm{C} \mathrm{m}^{-2} \mathrm{~d}^{-1}\right)$. Blue dots show NEE, with negative values indicating days in which the ecosystem is acting as a sink of C. Red triangles and green squares represent daily $R_{\text {eco }}$ and GPP obtained from flux partitioning of NEE data via LUT method.

while if $X$ and $Y$ were multiplied, the resulting $\mathrm{SEM}_{z}$ was calculated as follows:

$\operatorname{SEM}_{z}=Z \times \sqrt{\left(\frac{\operatorname{SEM}_{x}}{X}\right)^{2}+\left(\frac{\operatorname{SEM}_{y}}{Y}\right)^{2}}$.

\section{Results}

\subsection{The ecosystem carbon stocks and fluxes}

Soil was found to be by far the highest carbon pool, containing in the first $60 \mathrm{~cm}$ much more carbon than the standing biomass ( 21.3 vs. $1.2 \mathrm{~kg} \mathrm{C} \mathrm{m}^{-2}$ ). Data relative to the stocks of carbon and nitrogen within the ecosystem at the beginning of the growing season (March 2010) are reported in Table 2: the relative distribution of tree biomass dry weight, as well as $\mathrm{C}$ content, was $72 \%$ aboveground and $28 \%$ belowground, while $\mathrm{N}$ was $66 \%$ aboveground and $34 \%$ belowground.

\subsubsection{Fluxes from eddy covariance}

Figure 1 shows the daily ecosystem carbon fluxes of the apple orchard for the year 2010 assessed via eddy covariance. Budburst occurred on the 18 of March and NEE started to become negative (sink of C) during the first ten days of April and returned positive (source of $\mathrm{C}$ ) in the first decade of November, when leaf abscission was almost complete and only the vegetation on grassed alleys carried out photosynthesis. The maximum rate of NEE was 
Table 3. Parameters of the $Q_{10}$ model fitted for the contemporary measurements of soil respiration obtained by the multiplexed system and the survey chamber system.

\begin{tabular}{lcc}
\hline Methodology & $\mathrm{R}_{\mathrm{b}}$ & $Q_{10}$ \\
\hline Continuous measurements & $6.079 \pm 0.406$ & $1.221 \pm 0.061$ \\
Survey chamber & $4.668 \pm 0.498$ & $1.226 \pm 0.097$ \\
\hline
\end{tabular}

$-7.21 \mathrm{~g} \mathrm{C} \mathrm{m}^{-2} \mathrm{~d}^{-1}$ (25 June). On a yearly basis, GPP, $R_{\text {eco }}$ and NEP $(=-$ NEE) accounted for $1263 \pm 189,883 \pm 160$ and $380 \pm 30 \mathrm{~g} \mathrm{C} \mathrm{m}^{-2} \mathrm{yr}^{-1}$ respectively, according to the LUT method. Uncertainties were determined as standard error obtained from comparison with other interpolation algorithms for gap filling and flux partitioning. Following Reichstein et al. (2005), GPP was $1074, R_{\text {eco }} 723$ and NEP $351 \mathrm{~g} \mathrm{C} \mathrm{m}^{-2} \mathrm{yr}^{-1}$. Following Lasslop et al. (2010), these values were 945,433 and $512 \mathrm{~g} \mathrm{C} \mathrm{m}^{-2} \mathrm{yr}^{-1}$, respectively.

\subsubsection{Fluxes from soil respiration system}

Measured soil respiration $\left(R_{\mathrm{S}}\right)$ and its heterotrophic component $\left(R_{\mathrm{h}}\right)$ fluxes over the season are shown in Fig. 2. According to results from the spatial variability campaign, we found that continuous chamber measurements were taken in a spot where the $\mathrm{CO}_{2}$ efflux from the soil was above the average since they were done in a treeline (Fig. 3) and in positions (Fig. 4a), close to the trees, having high emission. A twosample $t$ test was carried out to compare $R_{\mathrm{S}}$ obtained from the two measurement systems. $R_{\mathrm{S}}$ was significantly higher in the multiplexed system $\left(\right.$ mean $\left.=8.21 \mu \mathrm{mol} \mathrm{CO}_{2} \mathrm{~m}^{-2} \mathrm{~s}^{-1}\right)$ than in survey chamber mode (mean $=6.54 \mu \mathrm{mol} \mathrm{CO}_{2} \mathrm{~m}^{-2} \mathrm{~s}^{-1}$; $t=9.996, p<0.001$, degree of freedom $=147$ ). Observed temperature sensitivity was similar, but the basal respiration, $R_{b}$, was larger in the spot where continuous measurements were taken (Table 3). Assuming that the observed relation between continuous and survey measurements was constant along the year, we calculated a constant multiplicative factor of 0.797 to upscale continuous measurements to the treelines and a second multiplicative factor of 0.831 to estimate the $R_{\mathrm{S}}$ in the grassed alleys (Fig. 4a). Total $R_{\mathrm{S}}$ resulted as the weighted average of these estimates.

By using the LUT method, upscaled $R_{\mathrm{S}}$ and $R_{\mathrm{h}}$ accounted for $801 \pm 95$ and $614 \pm 97 \mathrm{~g} \mathrm{C} \mathrm{m}^{-2} \mathrm{yr}^{-1}$, respectively. To assess the robustness of these estimates, we also modeled $R_{\mathrm{S}}$ by the $Q_{10}$ (van't Hoff, 1884) and by the Lloyd and Taylor (1994) models, and with both models the yearly amount of $R_{\mathrm{S}}$ and $R_{\mathrm{h}}$ were within the uncertainty levels mentioned above.

\subsubsection{Fluxes from biometric sampling}

The monthly results of the biometric measurements of NPP are shown in Fig. 5 and in Table 4 with related uncertainties.
Leaf production, $106 \pm 5 \mathrm{~g} \mathrm{C} \mathrm{m}^{-2} \mathrm{yr}^{-1}$, represented $11 \%$ of NPP. Leaf growth occurred mostly between April and early June, when leaves represented $44 \%$ of NPP. Reduced leaf growth was observed until September.

Fine root production showed three distinct peaks: the first one occurred before maximum leaf production, the second one just after it and a third one in October, after a reduced growth period in summer. On annual basis, NPPfr was $14 \%$ of NPP. Assuming that the increase in fine roots follows the same growth pattern as coarse roots, $\mathrm{C}$ allocated to standing fine roots is $6 \pm 1 \mathrm{~g} \mathrm{C} \mathrm{m}^{-2} \mathrm{yr}^{-1}$, while the remainder, $124 \pm 27 \mathrm{~g} \mathrm{C} \mathrm{m}^{-2} \mathrm{yr}^{-1}$, is supposed to be shed annually and to feed the detritus cycle.

The relative growth of woody organs was larger during spring and early summer (21\% of total NPP) and decreased to $8 \%$ from the end of August till the end of the vegetative season. On annual basis, $\mathrm{NPP} w_{\mathrm{AG}}$ was $173 \pm 53 \mathrm{~g} \mathrm{C} \mathrm{m}^{-2} \mathrm{yr}^{-1}$ (18\% of total NPP); the largest part of this component was accounted for by pruned wood feeding the detritus cycle $\left(147 \pm 45 \mathrm{~g} \mathrm{C} \mathrm{m}^{-2} \mathrm{yr}^{-1}\right)$, while the increment in standing wood biomass was $26 \pm 8 \mathrm{~g} \mathrm{C} \mathrm{m}^{-2} \mathrm{yr}^{-1}$. Carbon allocated to belowground structural organs accounted for only $1 \%$ of total woody NPP $\left(\mathrm{NPP} w_{\mathrm{BG}}=13 \pm 3 \mathrm{~g} \mathrm{C} \mathrm{m}^{-2} \mathrm{yr}^{-1}\right)$.

From June until the harvest, fruit represented the largest sink. Carbon allocation to this organ was more than $65 \%$ of total NPP in July and August and more that $75 \%$ of total NPP in September and October. On annual basis, carbon allocated to fruit was $495 \pm 35 \mathrm{~g} \mathrm{C} \mathrm{m}^{-2}$, equal to $52 \%$ of total NPP.

Aboveground primary production of the understory $(\mathrm{NPP} u)$ was a significant component of total NPP, accounting for $42 \pm 3 \mathrm{~g} \mathrm{C} \mathrm{m}^{-2}, 5 \%$ of total NPP, with a long growth period (March-November) and a relatively constant growth rate throughout the season.

The total $\mathrm{NPP}_{\text {biom }}$, obtained by the sum of the cumulated values of each considered NPP component (Table 5), was $960 \pm 70 \mathrm{~g} \mathrm{C} \mathrm{m}^{-2} \mathrm{yr}^{-1}$. Summarizing the fate of NPP components, we obtained that $45 \pm 9 \mathrm{~g} \mathrm{C} \mathrm{m}^{-2} \mathrm{yr}^{-1}$ represent an increase in standing biomass, $471 \pm 35 \mathrm{~g} \mathrm{C} \mathrm{m}^{-2} \mathrm{yr}^{-1}$ are exported and $444 \pm 53 \mathrm{~g} \mathrm{C} \mathrm{m}^{-2} \mathrm{yr}^{-1}$ feed the detritus cycle.

\subsection{Independent assessment of NPP, $R_{a}$, GPP and the overall carbon cycle}

Equations (2) and (3) show the relation among NPP, $R_{\mathrm{a}}$ and GPP and their importance for the determination of CUE. In this study the annual amount of each of these three $\mathrm{C}$ fluxes was obtained following at least two independent pathways.

The results of biomass accumulation of the ecosystem components considered at each sampling date are reported in Table 4, while Fig. 6 shows the daily carbon uptake rate of both $\mathrm{NPP}_{\text {biom }}$ and $\mathrm{NPP}_{\text {flux }}$. Daily $\mathrm{NPP}_{\text {biom }}$ showed a less regular annual pattern of $\mathrm{C}$ uptake with respect to $\mathrm{NPP}_{\text {flux }}$, which was bell shaped. Maximum daily NPP 

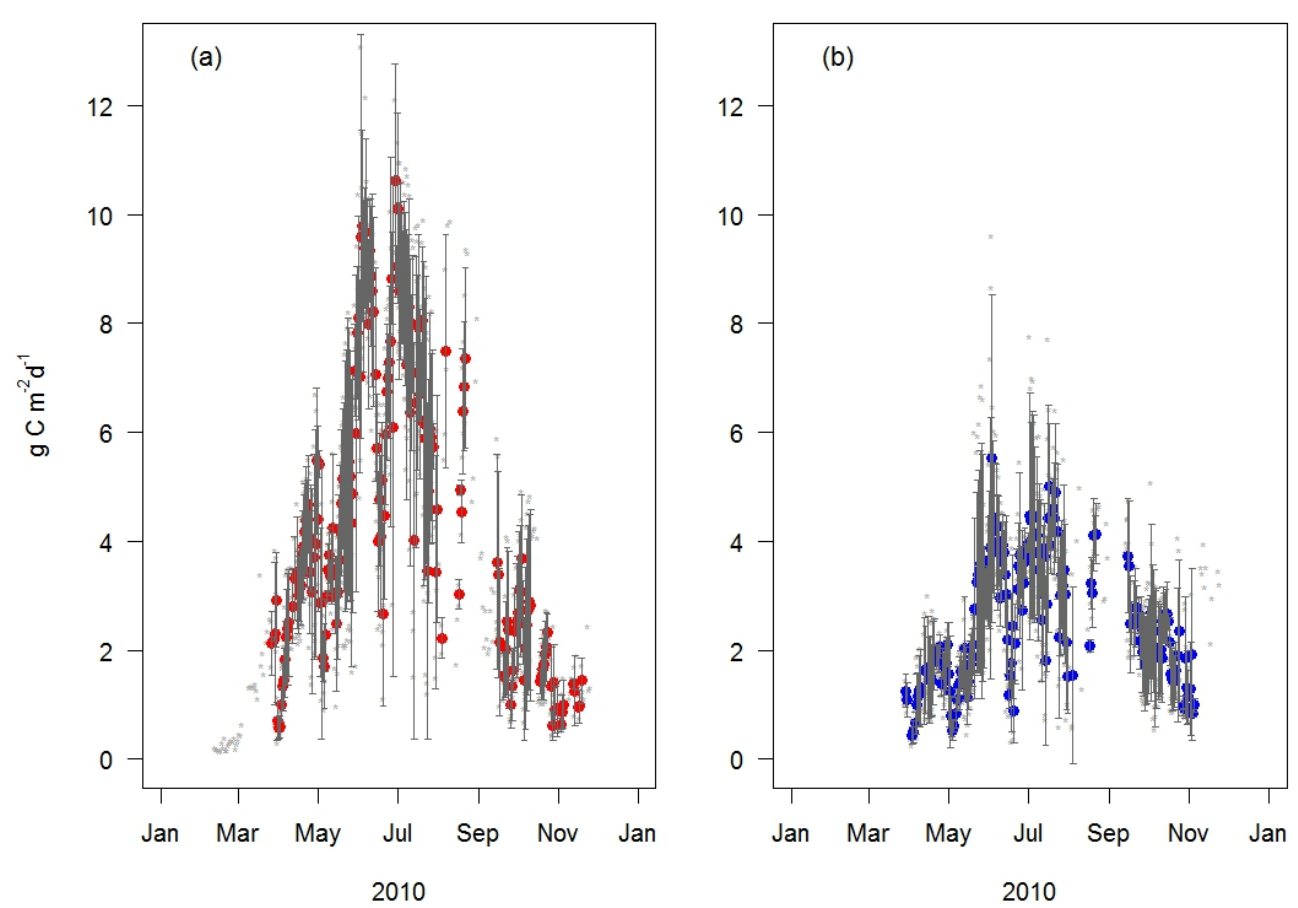

Fig. 2. Average daily soil respiration $\left(\mathrm{g} \mathrm{C} \mathrm{m}^{-2} \mathrm{~d}^{-1}\right)$ measured in control (a) and trenching plots (b) with the multiplexed system along the treeline. Data from each single collar are plotted with gray asterisks $\left(^{*}\right)$. Dots represent daily $R_{\mathrm{S}}(\mathbf{a})$ and $R_{\mathrm{h}}(\mathbf{b})$, when data from at least three chambers passed the quality test. Bars are standard deviation of the mean.

Table 4. Biomass production ( $\mathrm{g} \mathrm{DW} \mathrm{m}^{-2} \pm$ standard error) in the monitored tree organs between each sampling date.

\begin{tabular}{lccccccc}
\hline Sampling date & Leaves & Fruit & wood $_{\mathrm{AG}}$ & wood $_{\mathrm{BG}}$ & Fine roots & Understory & Total \\
\hline 20 Apr 2010* & $32.7 \pm 1.7$ & 0 & $26.9 \pm 59.1$ & $-0.6 \pm 3.4$ & $85.9 \pm 45.6$ & $9.0 \pm 1.2$ & $153.8 \pm 74.7$ \\
11 May 2010 & $108.2 \pm 5.5$ & $29.4 \pm 4.6$ & $75.8 \pm 31.1$ & $9.6 \pm 4.0$ & $22.7 \pm 52.7$ & $4.3 \pm 0.1$ & $250.1 \pm 61.7$ \\
23 Jun 2010 & $48.6 \pm 6.2$ & $194.5 \pm 41.2$ & $79.6 \pm 21.4$ & $9.3 \pm 1.7$ & $87.8 \pm 59.0$ & $20.1 \pm 4.4$ & $440.0 \pm 75.4$ \\
15 Jul 2010 & $22.8 \pm 4.2$ & $273.5 \pm 54.9$ & $75.1 \pm 68.1$ & $1.9 \pm 3.2$ & $17.9 \pm 65.5$ & $17.3 \pm 1.5$ & $408.5 \pm 109.4$ \\
20 Aug 2010 & $7.8 \pm 2.5$ & $266.4 \pm 57.7$ & $89.8 \pm 54.1$ & $7.2 \pm 1.9$ & $15.0 \pm 48.0$ & $20.0 \pm 2.6$ & $406.2 \pm 92.6$ \\
15 Sep 2010 & $12.4 \pm 3.4$ & $294.3 \pm 61.4$ & $30.4 \pm 30.4$ & $1.1 \pm 1.1$ & $10.8 \pm 51.6$ & $24.3 \pm 3.8$ & $373.3 \pm 85.9$ \\
14 Oct 2010 & 0 & $181.2 \pm 33.7$ & $17.5 \pm 9.3$ & $2.6 \pm 1.2$ & $35.5 \pm 75.2$ & $8.3 \pm 2.3$ & $245.1 \pm 83.0$ \\
16 Nov 2010 & 0 & 0 & $-13.3 \pm 9.6$ & $-1.8 \pm 1.1$ & $16.3 \pm 78.1$ & 0 & $16.3 \pm 78.1$ \\
\hline Total & $232 \pm 10$ & $1239 \pm 88$ & $382 \pm 117$ & $29 \pm 7$ & $292 \pm 62$ & $103 \pm 6$ & $2278 \pm 160$ \\
\hline
\end{tabular}

* Data of the first sampling refer to biomass production from bud burst.

occurred from mid-June until mid-July for both $\mathrm{NPP}_{\text {biom }}$ $\left(7.80 \pm 2.18 \mathrm{~g} \mathrm{C} \mathrm{m}^{-2} \mathrm{~d}^{-1}\right)$ and $\mathrm{NPP}_{\text {flux }}\left(10.32 \mathrm{~g} \mathrm{C} \mathrm{m}^{-2} \mathrm{~d}^{-1}\right)$.

Although some discrepancies emerge when comparing the two curves $\left(\mathrm{NPP}_{\text {flux }}-\mathrm{NPP}_{\text {biom }}=-2.9 \mathrm{~g} \mathrm{C} \mathrm{m}^{-2} \mathrm{~d}^{-1}\right.$ in May, $-1.5 \mathrm{~g} \mathrm{C} \mathrm{m}^{-2} \mathrm{~d}^{-1}$ in September, $+1.3 \mathrm{C} \mathrm{m}^{-2} \mathrm{~d}^{-1}$ in November), we found good agreement between these two independent methods of determining NPP, confirmed by the surprisingly close value of yearly $\mathrm{NPP}_{\text {biom }}$ and $\mathrm{NPP}_{\text {flux }}$ values, which were $960 \pm 70$ and $994 \pm 101 \mathrm{~g} \mathrm{C} \mathrm{m}^{-2} \mathrm{yr}^{-1}$, respectively.

As mentioned above, $R_{\mathrm{a}}$ was the only element of the $\mathrm{C}$ cycle that was not measured directly. Each of the three equations applied implies the integration of different method- ologies and leads to sensible different estimates of $R_{\mathrm{a}}$ (Table 6). Following Eq. (8), $R_{\mathrm{a}}$ was $303 \pm 202 \mathrm{~g} \mathrm{C} \mathrm{m}^{-2} \mathrm{yr}^{-1}$, a value close to the result of Eq. (9), which leads to a $R_{\mathrm{a}}$ of $269 \pm 187 \mathrm{~g} \mathrm{C} \mathrm{m}^{-2} \mathrm{yr}^{-1}$. The third method, Eq. (10), relying on soil chamber methodology and measurements on $\mathrm{N}$ content in the biomass, gives estimates significantly higher with respect to the previous two, with $R_{\mathrm{a}}$ being $545 \pm 195 \mathrm{~g} \mathrm{C} \mathrm{m}^{-2} \mathrm{yr}^{-1}$.

On a yearly basis, it was possible to estimate GPP independently from EC measurements. $\mathrm{GPP}_{\mathrm{BS}}$ was obtained by summing $\mathrm{NPP}_{\text {biom }}$ with $R_{\mathrm{a}}$ determined by Eq. (10), therefore relying only on biometric and soil chamber measurements. While $\mathrm{GPP}_{\mathrm{EC}}$ was $1263 \pm 189 \mathrm{~g} \mathrm{C} \mathrm{m}^{-2} \mathrm{yr}^{-1}$, 
Table 5. Yearly NPP values of the ecosystem components measured biometrically (data are expressed in $\mathrm{gDW} \mathrm{m}^{-2} \mathrm{yr}^{-1}$ and $\mathrm{g} \mathrm{C} \mathrm{m}^{-2} \mathrm{yr}^{-1} \pm$ standard error of the mean).

\begin{tabular}{lrrrrr}
\hline NPP component & $\mathrm{DW}\left(\mathrm{g} \mathrm{m}^{-2} \mathrm{yr}^{-1}\right)$ & $\mathrm{DW}(\%)$ & $\mathrm{gC} \mathrm{g} \mathrm{DW}^{-1}$ & ${\mathrm{C}\left(\mathrm{g} \mathrm{m}^{-2} \mathrm{yr}^{-1}\right)}^{\mathrm{C}(\%)}$ \\
\hline $\mathrm{NPP} l$ & $232 \pm 10$ & 10 & 0.458 & $106 \pm 5$ & 11 \\
$\mathrm{NPP} f$ & $1239 \pm 88$ & 55 & 0.400 & $495 \pm 35$ & 52 \\
$\mathrm{NPP} w_{\text {AG }}$ & $382 \pm 117$ & 17 & 0.454 & $173 \pm 53$ & 18 \\
$\mathrm{NPP} w_{\mathrm{BG}}$ & $29 \pm 7$ & 1 & 0.453 & $13 \pm 3$ & 1 \\
$\mathrm{NPP} f r$ & $292 \pm 62$ & 13 & 0.444 & $130 \pm 28$ & 14 \\
$\mathrm{NPP} u$ & $103 \pm 6$ & 5 & 0.410 & $42 \pm 3$ & 4 \\
$\mathrm{NPPtotal}$ & $2278 \pm 160$ & 100 & & $960 \pm 70$ & 100 \\
\hline
\end{tabular}

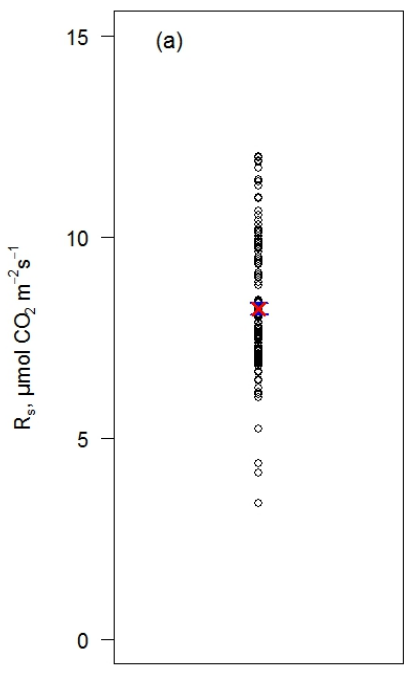

Continuous measurements

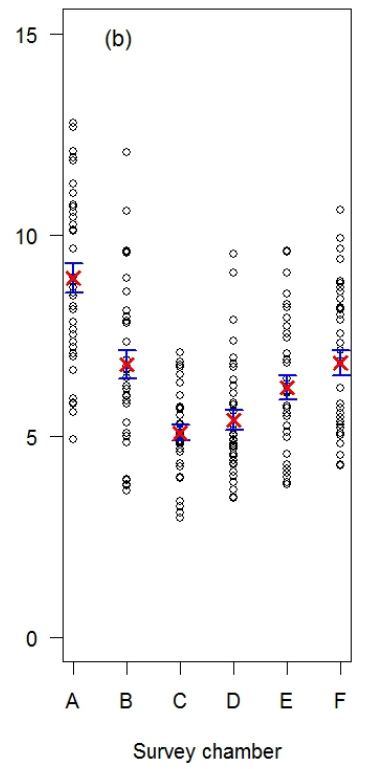

Fig. 3. Comparison of $R_{\mathrm{s}}$ data $\left(\mu \mathrm{mol} \mathrm{CO} \mathrm{CO}^{2} \mathrm{~s}^{-1}\right)$ obtained from the multiplexed system (a) with those obtained from the survey chamber (b). Crosses indicate the average value; blue bars indicate the standard error. All the measurements were taken along the treeline in the same time period (24-30 June 2010), to account for the variability within the orchard treelines. Letters (A to F) represent the six plots of the survey campaign.

$\mathrm{GPP}_{\mathrm{BS}}$ was approximately $250 \mathrm{~g} \mathrm{C} \mathrm{m}^{-2} \mathrm{yr}^{-1}$ greater $\left(1505 \pm 207 \mathrm{~g} \mathrm{C} \mathrm{m}^{-2} \mathrm{yr}^{-1}\right)$.

All the $\mathrm{C}$ fluxes measured within the ecosystem during 2010, and lateral import and export, are shown in Fig. 7. The $R_{\mathrm{a}}$ value reported in Fig. $7\left(372 \pm 195 \mathrm{~g} \mathrm{C} \mathrm{m}^{-2} \mathrm{yr}^{-1}\right)$ refers to the average \pm se of $R_{\mathrm{a}}$ obtained by Eqs. (8), (9) and (10) presented in Table 6 .

\subsection{CUE: seasonal trend and yearly value}

The seasonal trend of $\mathrm{CUE}_{\text {biom }}$ and $\mathrm{CUE}_{\text {flux }}$ is shown in Fig. 8. Significant differences between the two estimates occurred at the beginning of the growing season and at its end, after harvest. When analyzed separately, $\mathrm{CUE}_{\text {biom }}$ showed
Table 6. Computed values of $R_{\mathrm{a}}( \pm \mathrm{se})$ obtained from the three methodologies discussed in Sect. 2.4 (Eqs. 8, 9 and 10). The coefficient $k$ obtained from the ratio between total and BG nitrogen content in the standing biomass was $2.92 \pm 0.27$. The average $R_{\mathrm{a}}$ value $\left(372 \pm 195 \mathrm{~g} \mathrm{C} \mathrm{m}^{-2} \mathrm{yr}^{-1}\right)$ is reported in Fig. 7 .

\begin{tabular}{lllc}
\hline & Model & Methodology & $R_{\mathrm{a}}\left(\mathrm{g} \mathrm{C} \mathrm{m}^{-2} \mathrm{yr}^{-1}\right)$ \\
\hline 1 & $\mathrm{GPP}^{-N P P} \mathrm{biom}_{\text {biom }}$ & EC - biometric & $303 \pm 202$ \\
2 & $R_{\mathrm{eco}}-R_{\mathrm{h}}$ & EC - soil chambers & $269 \pm 187$ \\
3 & $k\left(R_{\mathrm{a} \_\mathrm{BG}}\right)$ & Soil chambers & $545 \pm 195$ \\
\hline
\end{tabular}

Table 7. The four approaches used to assess the CUE ( \pm se) of the studied apple orchard. (average $=0.71 \pm 0.12$ ).

\begin{tabular}{lc}
\hline Model & $\mathrm{CUE}$ \\
\hline $\mathrm{NPP}_{\text {biom }} / \mathrm{GPP}_{\mathrm{EC}}$ & $0.76 \pm 0.13$ \\
$\mathrm{NPP}_{\text {flux }} / \mathrm{GPP}_{\mathrm{EC}}$ & $0.79 \pm 0.14$ \\
$\mathrm{NPP}_{\text {biom }} / \mathrm{GPP}_{\mathrm{BS}}$ & $0.64 \pm 0.10$ \\
$\mathrm{NPP}_{\text {flux }} / \mathrm{GPP}_{\mathrm{BS}}$ & $0.66 \pm 0.11$ \\
\hline
\end{tabular}

an irregular pattern with a decreasing trend throughout the season, while $\mathrm{CUE}_{\text {flux }}$ showed its highest values during the summer months. In both cases CUE was above 0.5 for the whole growing season. Based on results shown in the previous sections, on a yearly basis we obtained four estimates of CUE and their respective standard errors (Table 7), giving an average value of $0.71 \pm 0.12$.

\section{Discussion}

\subsection{Magnitude of $\mathrm{C}$ fluxes}

The first hypothesis of this study was that the main ecosystem $\mathrm{C}$ fluxes of a woody agro-ecosystem have the same order of magnitude as natural forest ecosystems growing in the same biome rank. Table 8 shows a comparison between meteorological and biological variables measured at the study site and at the temperate-humid deciduous forests reported in the global forests database published by Luyssaert et al. (2007). 

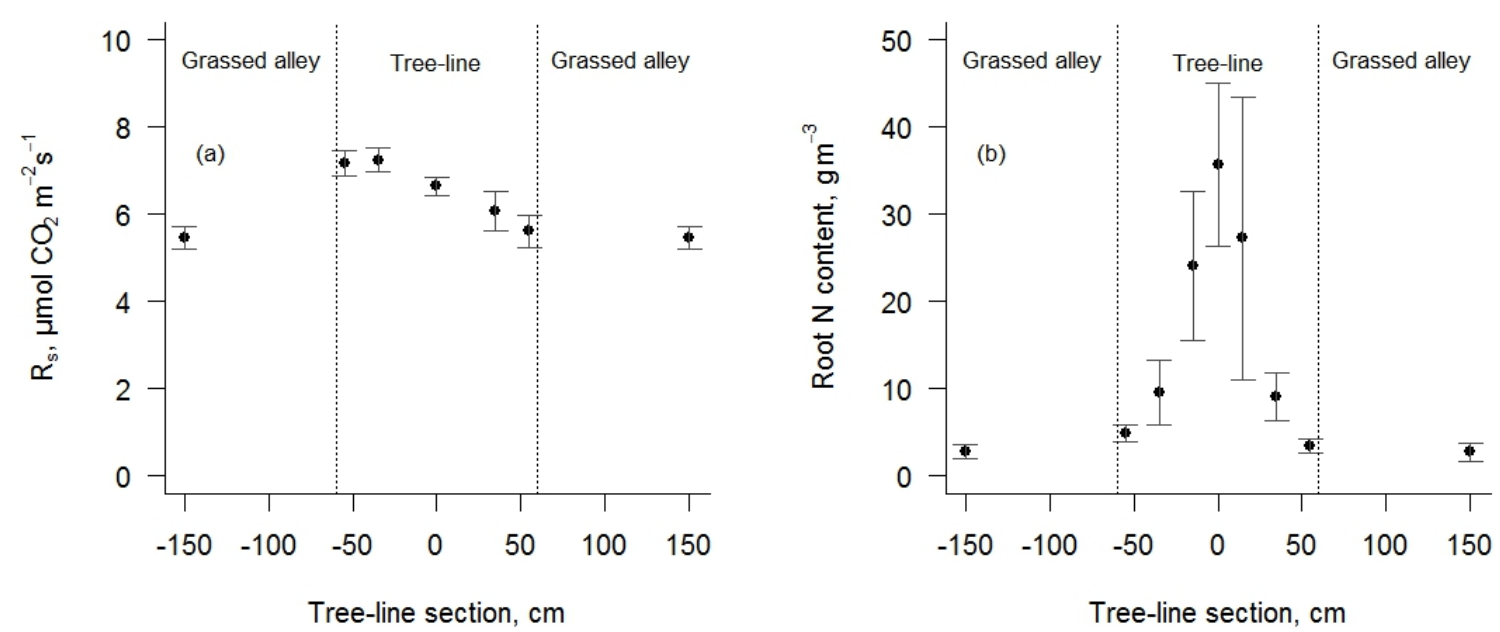

Fig. 4. Soil respiration $\left(\mathbf{a}, \mu \mathrm{mol} \mathrm{CO}_{2} \mathrm{~m}^{2} \mathrm{~s}^{-1}\right)$ and $\mathrm{N}$ content in root biomass $\left(\mathbf{b}, \mathrm{g} \mathrm{N} \mathrm{m}^{-3}\right.$ soil $)$ measured across the treeline and the grassed alley, where "zero" indicates the position of the apple tree. Measurements were performed in the six different plots used for the spatial survey. Bars represent standard error (se) of the mean.

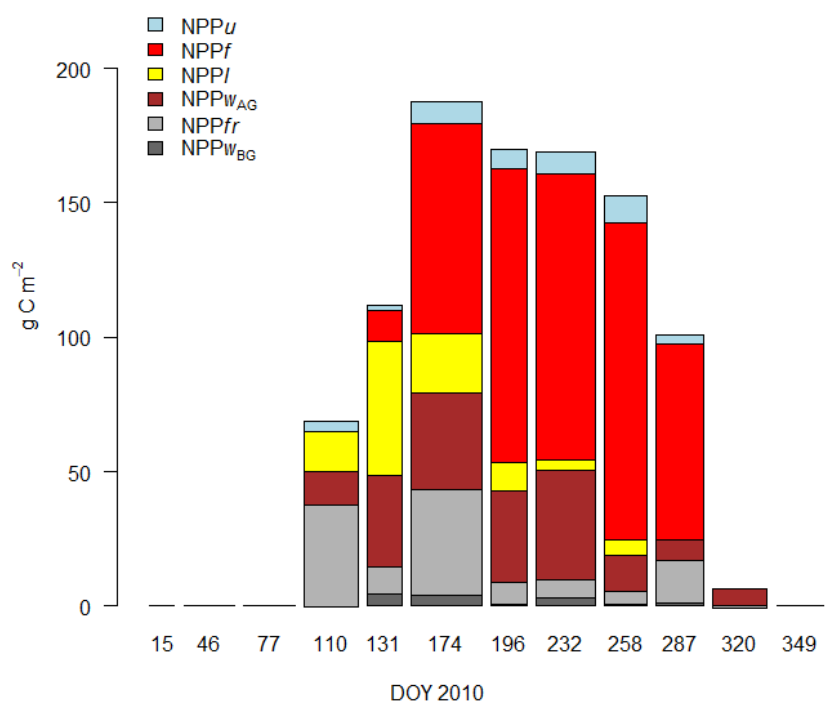

Fig. 5. NPP $\left(\mathrm{g} \mathrm{C} \mathrm{m}^{-2}\right)$ between each sampling date interval calculated in the six considered ecosystem compartments. Bars' width reflects the time (in days) that occurred between successive biometric samplings.

Regarding the average ecosystem characteristics, it appears that apple trees are smaller in size (height, AG and BG biomass) with respect to trees growing in forests, and have a smaller LAI since they are kept structurally similar to young forest, although with a lower stem density (Luyssaert et al., 2008). Climate characteristics of the study site are very similar to the average observed in temperate-humid forests, with the exception of summer precipitation; in the apple orchard, water was additionally supplied by irrigation - a practice that eliminates major stress due to drought in the summer period. Based on our results, EC ecosystem carbon fluxes (GPP, NEP

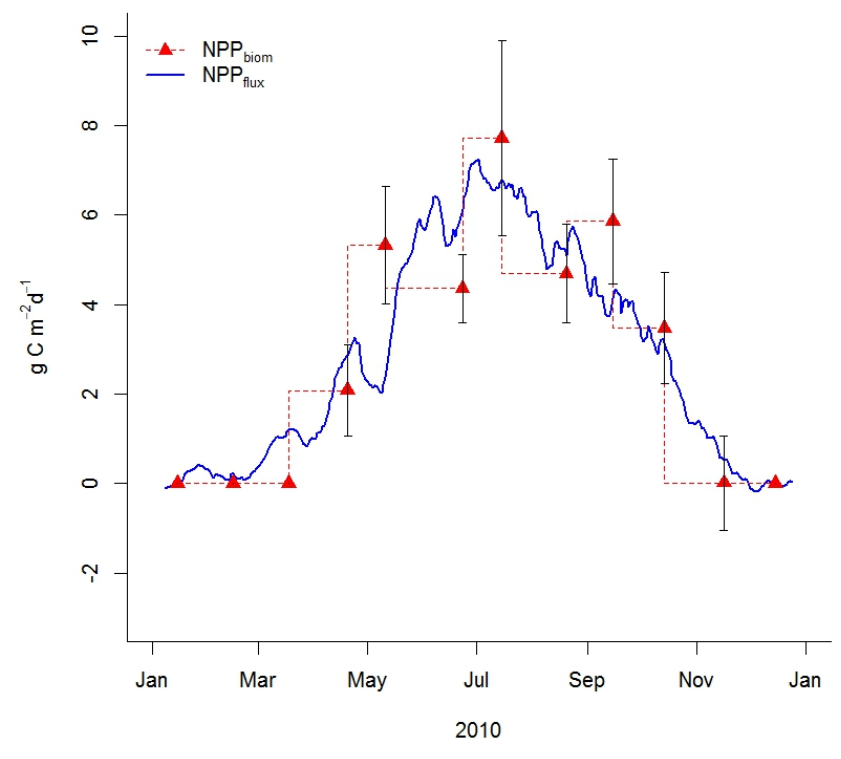

Fig. 6. Annual pattern of NPP $\left(\mathrm{g} \mathrm{C} \mathrm{m}^{-2} \mathrm{~d}^{-1}\right)$. The dashed line represents daily NPP obtained from biometric measurements $\left(\mathrm{NPP}_{\text {biom }}\right)$ and the solid line represents the 15 days moving average of NPP obtained by summing the daily fluxes of $R_{\mathrm{h}}$ and $\mathrm{NEP}\left(\mathrm{NPP}_{\text {flux }}\right)$. Bars represent standard error (se) of the mean daily $\mathrm{NPP}_{\text {biom }}$.

and $R_{\text {eco }}$ ) obtained in the studied agro-ecosystem are quantitatively similar to a forested stand. We obtained slightly lower GPP and $R_{\text {eco }}$ values and a larger NEP, but differences were within $100 \mathrm{~g} \mathrm{C} \mathrm{m}^{-2} \mathrm{yr}^{-1}$.

The estimate of $R_{\mathrm{h}}$ was obtained by measuring $R_{\mathrm{S}}$ from trenching plots. This methodology for separating microbial and root respiration is widely applied for its simplicity and low cost, although it has several disadvantages 


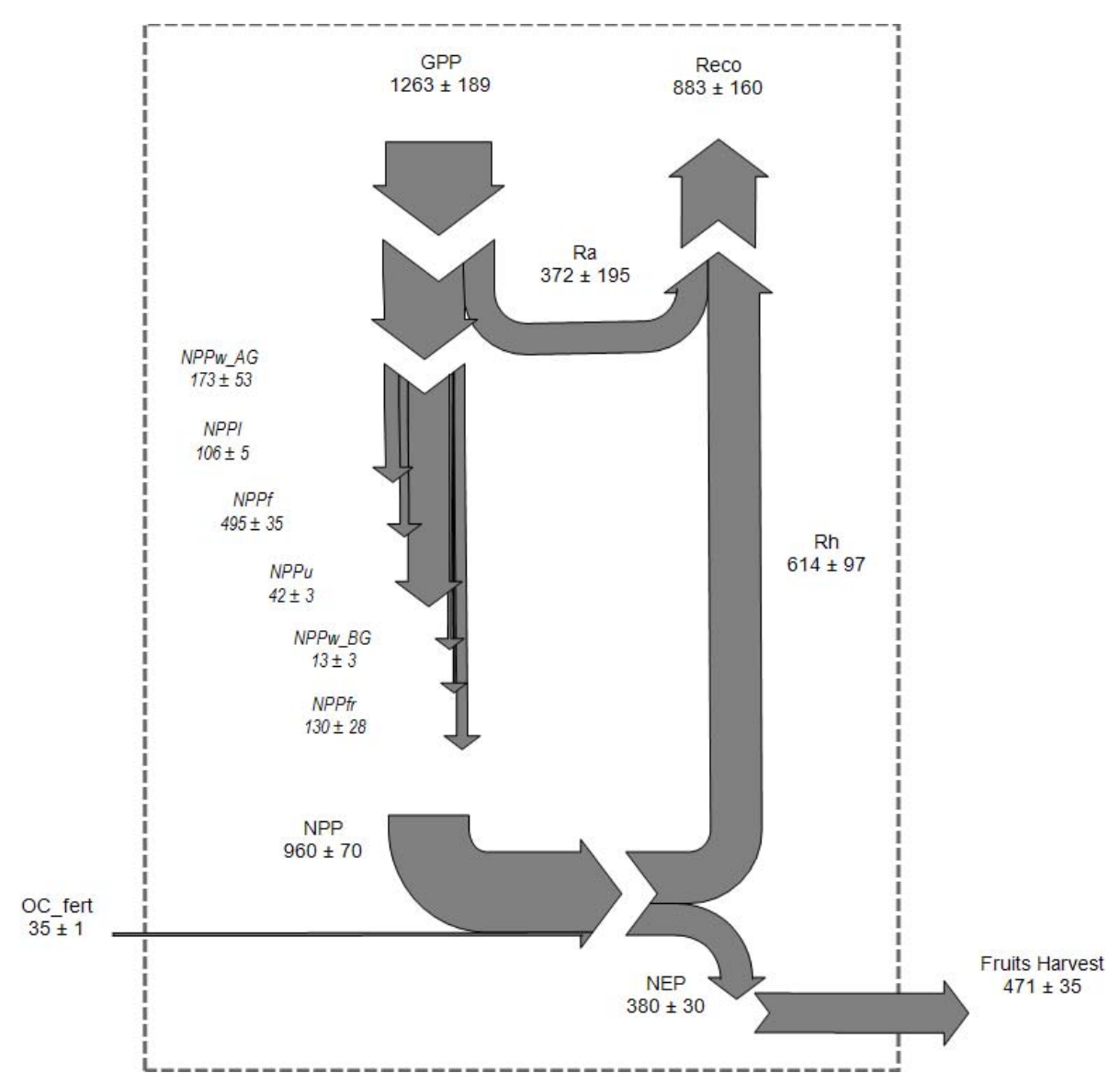

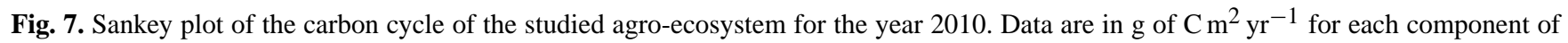
the $\mathrm{C}$ cycle. Arrows' width reflects the flux size. GPP = gross primary production; $\mathrm{Ra}=$ autotrophic respiration; Reco $=$ ecosystem respiration; $\mathrm{Rh}=$ heterotrophic respiration; $\mathrm{NPP}=$ net primary productivity; $\mathrm{NPP} w_{\mathrm{AG}}=$ aboveground wood $\mathrm{NPP} ; \mathrm{NPP} l=\mathrm{leaf} \mathrm{NPP} ; \mathrm{NPP} f=$ fruit $\mathrm{NPP} ; \mathrm{NPP} u=$ understory NPP; NPP $w_{\mathrm{BG}}=$ belowground wood NPP; NPP $f r=$ fine roots NPP; $\mathrm{OC}_{\text {fert }}=$ organic carbon content of fertilizer; $\mathrm{NEP}=$ net ecosystem productivity; Fruit Harvest $=$ fruit production exported from the ecosystem.

(Subke et al., 2006; Lambert et al., 2011). Among them, the most important is probably the fact that part of the measured $\mathrm{C}$ may come from decomposition of roots that are excised during the trenching process (Hanson at al., 2000). Following Fahey et al. (1988) and Bowden et al. (1993), we minimized the priming effect due to an excess of decomposable matter (Kuzyakov et al., 2000) starting the measurements approximately 10 months after the trenching plots were set. Another problem could arise because of the higher soil water content of trenching with respect to the control sample due to the absence of root absorption. This may cause a change in the microbial community and in the rate of $\mathrm{CO}_{2}$ emission (DìazPìnes et al., 2010) that we prevented starting from June 2010 by installing a plastic shelter approximately $1 \mathrm{~m}$ above the trenching plot. It has also been suggested that small trenching acts as a sink for $\mathrm{CO}_{2}$ from surrounding soil (Rachpal et al., 2006), thus causing an overestimation of $R_{\mathrm{h}}$. Despite all limitations of the trenching approach and the assumptions that need to be made, the meta-analytical review published by Subke et al. (2006) reports general good agreement among different methodologies in soil respiration partitioning, reinforcing the reliability of our estimates.

The ratio $R_{\mathrm{h}} / R_{\mathrm{S}}$ obtained in the present study (0.77) is within the range of the studies carried out over temperate forests, as reviewed by Subke et al. (2006), and higher than the value (0.65) reported in an apple orchard by Panzacchi et al. (2012). Our average $R_{\mathrm{h}}\left(614 \pm 97 \mathrm{~g} \mathrm{C} \mathrm{m}^{-2} \mathrm{yr}^{-1}\right)$ is also higher when compared to the average $R_{\mathrm{h}}$ values reported by Luyssaert et al. (2007) for temperate-humid deciduous forests ( $387 \pm 4 \mathrm{~g} \mathrm{C} \mathrm{m}^{-2} \mathrm{yr}^{-1}$, Table 3 ). Other than the uncertainties of the methodology itself, this may also be due to a relatively high soil organic carbon content and to the superficial soil tillage that was periodically carried out along the apple tree strip ( $1.2 \mathrm{~m}$ wide) to control the growth of grass below the trees, a common practice in an organic production system (Reganold et al., 2001; Smith, 2004). 
Table 8. Table of comparison between natural woody ecosystems of temperate-humid biomes (dataset of Luyssaert et al., 2007) and the studied apple orchard, a woody agro-ecosystem.

\begin{tabular}{|c|c|c|}
\hline Stand characteristics $($ mean $\pm \mathrm{SD}$ ) & Temperate-humid deciduous forest & Apple orchard (2010) \\
\hline Latitude $\left(^{\circ}\right)$ & $44 \pm 9$ & 46 \\
\hline $\operatorname{Max} \operatorname{LAI}\left(\mathrm{m}^{2} \mathrm{~m}^{-2}\right)$ & $6.1 \pm 3.5$ & 2.8 \\
\hline Tree height (m) & $19 \pm 7$ & 4 \\
\hline Tree density (number ha ${ }^{-1}$ ) & $1723 \pm 2439$ & 3330 \\
\hline Stand age & $75 \pm 50$ & 11 \\
\hline AG biomass $\left(\mathrm{g} \mathrm{C} \mathrm{m}^{-2}\right)$ & $10882 \pm 5670$ & $841 \pm 81$ \\
\hline BG biomass $\left(\mathrm{g} \mathrm{C} \mathrm{m}^{-2}\right)$ & $2565 \pm 2609$ & $320 \pm 15$ \\
\hline \multicolumn{3}{|l|}{ Stand climate (mean $\pm \mathrm{SD}$ ) } \\
\hline Mean winter temperature $\left({ }^{\circ} \mathrm{C}\right)$ & $2 \pm 9$ & $1 \pm 4$ \\
\hline Mean summer temperature $\left({ }^{\circ} \mathrm{C}\right)$ & $20 \pm 5$ & $22 \pm 5$ \\
\hline Precipitation sum winter (mm) & $183 \pm 164$ & 152 \\
\hline Precipitation sum summer (mm) & $356 \pm 259$ & $293\left(+250^{*}\right)$ \\
\hline Mean winter air humidity $(\%)$ & $79 \pm 11$ & $72 \pm 23$ \\
\hline Mean summer air humidity $(\%)$ & $77 \pm 5$ & $62 \pm 23$ \\
\hline \multicolumn{3}{|l|}{ Mean $C$ fluxes (mean $\pm S E)$} \\
\hline GPP & $1375 \pm 12(n=22)$ & $1263 \pm 189$ \\
\hline NPP & $738 \pm 8(n=52)$ & $960 \pm 70$ \\
\hline $\mathrm{NPPl}$ & $235 \pm 2(n=32)$ & $106 \pm 5$ \\
\hline $\mathrm{NPP} w_{\mathrm{AG}}$ & $329 \pm 10(n=21)$ & $173 \pm 53$ \\
\hline $\mathrm{NPP} f r+\mathrm{NPP} w_{\mathrm{BG}}$ & $207 \pm 3(n=52)$ & $143 \pm 28$ \\
\hline NPP $f$ & n.a. & $495 \pm 35$ \\
\hline $\mathrm{NPP} u$ & n.a. & $42 \pm 3$ \\
\hline NEP & $311 \pm 7(n=29)$ & $380 \pm 30$ \\
\hline$R_{\text {eco }}$ & $1048 \pm 13(n=24)$ & $883 \pm 160$ \\
\hline$R_{\mathrm{a}}$ & $673 \pm 22(n=15)$ & $372 \pm 195$ \\
\hline$R_{\mathrm{h}}$ & $387 \pm 4(n=40)$ & $614 \pm 67$ \\
\hline CUE & $0.54 \pm 0.01$ & $0.71 \pm 0.12$ \\
\hline
\end{tabular}

* Amount of water (mm) added by irrigation.

The protocol that was used to biometrically assess NPP accounts for four (out of six) hierarchical levels of the framework for NPP that was proposed by Luyssaert et al. (2007). We did not account for neither photosynthates released to symbionts or as root exudates, nor for non- $\mathrm{CO}_{2}$ carbon emission $\left(\mathrm{VOC}, \mathrm{CO}, \mathrm{CH}_{4}\right)$. Thus, apart from uncertainties in the estimates of the other NPP components, the biometric value we found $\left(960 \pm 70 \mathrm{~g} \mathrm{C} \mathrm{m}^{-2} \mathrm{yr}^{-1}\right)$ is likely to be an underestimation of the real NPP. There are few reliable estimations of the magnitude of the root exudates component and non- $\mathrm{CO}_{2}$ carbon emissions on total NPP in the literature (Grayston et al., 1997; Millard et al., 2007). These are often accounted as missing NPP due to the intrinsic difficulty of their direct assessment (Luyssaert et al., 2007) under field conditions. In the review of ${ }^{14} \mathrm{C}$ labeling studies on plant-soil interactions published by Farrar et al. (2003), it is suggested that exudation may account for 5-10\% of net $\mathrm{C}$ assimilation, although Jones et al. (2004) revised this estimation to $2-4 \%$ and other studies pointed out the dependency of the amount of root exudates on plant species, soil type, fertility and other climatic variables (Cheng et al., 2007; Jones et al., 2009; Scandellari et al., 2007; Vicca et al., 2012). The NPP found in this study was about $200 \mathrm{~g} \mathrm{C} \mathrm{m}^{-2} \mathrm{yr}^{-1}$ higher with respect to natural forests of the same biome rank (Table 8). In a less productive and less vigorous apple genotype, Panzacchi et al. (2012) have also found an average NPP value of $785 \mathrm{~g} \mathrm{C} \mathrm{m}^{-2} \mathrm{yr}^{-1}$. The presence of a large amount of fruit on an apple tree is known to enhance specific leaf photosynthesis as a consequence of their role as a sink, which allows for a more rapid download of photosynthates from the phloem with respect to apple trees not bearing fruit (Giuliani et al., 1997; Tartachnyk and Blanke, 2004).

\subsection{Annual and seasonal $\mathrm{C}$ allocation pattern}

The second hypothesis of this study was that the main differences between natural and agricultural woody ecosystems lie in the allocation pattern of fixed $\mathrm{C}$ instead of in a different magnitude of $\mathrm{C}$ fluxes. Results from this study confirm this hypothesis, highlighting how this agro-ecosystem is 


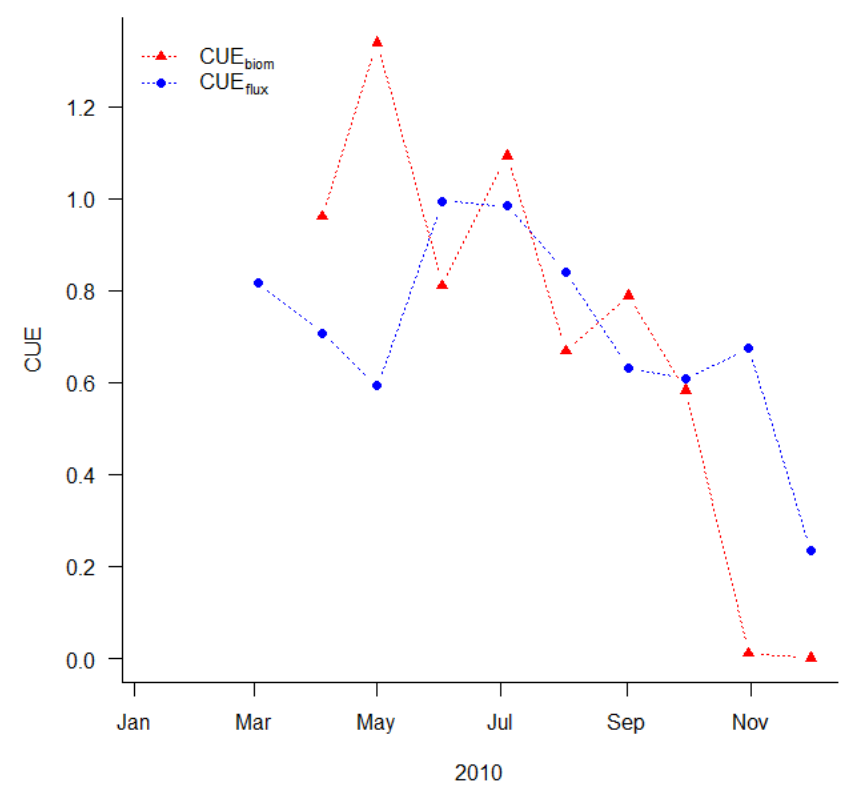

Fig. 8. Seasonal trend of the carbon use efficiency. Triangles represent CUE values obtained by dividing $\mathrm{NPP}_{\text {biom }}$ and $\mathrm{GPP}_{\mathrm{EC}}$ $\left(\mathrm{CUE}_{\text {biom }}\right)$; circles indicate CUE values obtained from the ratio between $\mathrm{NPP}_{\text {flux }}$ and $\mathrm{GPP}_{\mathrm{EC}}\left(\mathrm{CUE}_{\text {flux }}\right)$. Time period considered is the growing season 2010, from DOY 77 till DOY 291.

strongly oriented to fruit production. While deciduous forests of temperate-humid biomes allocate the fixed $\mathrm{C}$ primarily into leaves, wood and roots, with an incidence on total NPP of 30, 43 and $27 \%$, respectively (Table 8), these three NPP components in the studied orchard accounted for only 11 , 18 and $15 \%$ of total NPP, with fruit being by far the major NPP contributor ( $495 \pm 35 \mathrm{~g} \mathrm{C} \mathrm{m}^{-2} \mathrm{yr}^{-1}, 52 \%$ of total NPP). When analyzing the seasonal trend of the $\mathrm{C}$ allocation pattern, it can be noticed that roughly $70 \%$ of the leaves are set within 2 months after budburst, while aboveground woody organs show a constant growth until mid-August. Most root NPP is due to fine root production since apple trees are grafted on dwarfing rootstock and thus new coarse root production is rather limited. Results on fine root growth are consistent with findings published by Eissenstadt et al. (2006). The overall amount of fine root released to detritus cycle also agrees with findings of Wells and Eissenstadt (2001).

The apple orchard is also affected by significant lateral flows of $\mathrm{C}$ due to human activities which occur, with a different magnitude, in both inputs and outputs. As lateral $\mathrm{C}$ input, we must consider organic fertilization, a common agricultural practice repeated every year for ensuring the reintegration of exported mineral nutrients, which accounted for about $35 \mathrm{~g} \mathrm{C} \mathrm{m}^{-2} \mathrm{yr}^{-1}$. The lateral $\mathrm{C}$ output flow is quantitatively much more important since it is represented by the harvested apples that are taken away from the ecosystem for commercial purposes. In 2010 this component was quantified as $471 \pm 35 \mathrm{~g} \mathrm{C} \mathrm{m}^{-2} \mathrm{yr}^{-1}\left(74 \mathrm{tha}^{-1}\right.$ fresh weight, corresponding to $95 \%$ of NPP $f$ ), while the re- maining $5 \%$ is accounted for by early drops and uncollected fruit $\left(24 \pm 3 \mathrm{~g} \mathrm{C} \mathrm{m}^{-2} \mathrm{yr}^{-1}\right)$ that enter the detritus cycle. The estimated fruit production is slightly higher than the average yields observed in this area of intense apple production (approx. $60 \mathrm{tha}^{-1}$ ).

The fate of the $\mathrm{C}$ contained in the abscised leaves of apple trees during their decomposition on the soil surface has been reported by Tagliavini et al. (2007), who showed that approximately $80 \%$ of initial amounts are lost in the first $2 \mathrm{yr}$ after leaf abscission. Ventura et al. (2009) reported that the decomposition of peach leaf litter is complete after $3 \mathrm{yr}$ and about $10 \%$ of initial amounts of leaf $\mathrm{C}$ are likely to be transformed into more stable $\mathrm{C}$ forms in the soil.

Our findings are consistent with other studies on apple trees of different growing conditions and varieties (Palmer, 1988; Minchin et al., 1997; Faqi et al., 2008), while a similar incidence of fruit production on total NPP was also found in other agro-ecosystems, such as a coconut palm plantation (Navarro et al., 2008), peach (Chalmers and van den Ende, 1975), orange (Liguori et al., 2009) and kiwifruit orchards (Rossi et al., 2007). For comparison with other croplands see Ciais et al. (2010).

The fate of allocated carbon is partially different from forests, with a fraction of $\mathrm{C}$ exported from the ecosystem through apple production representing nearly half of total net primary production. About $46 \%$ of annual NPP feeds the detritus cycle, and this is similar to natural forests if tree mortality is not considered (e.g., Tan et al., 2011), giving ample potential for the soil of the fruit tree ecosystem to act as a net carbon sink. The amount of NPP that increases the standing biomass, contributing to ecosystem $\mathrm{C}$ storage function $(5 \%$ of total NPP), is conversely much lower than in forests.

\subsection{Independent assessment of NPP, $R_{\mathrm{a}}$ and GPP}

The methodological approach employed in the present study gave the opportunity to assess $\mathrm{C}$ fluxes involved in CUE determination through independent pathways. This allowed a cross check of the estimated fluxes, thus obtaining an important feedback on the robustness of the estimation.

NPP was assessed by using only biometric measurements of different ecosystem components ( $\left.\mathrm{NPP}_{\text {biom }}\right)$ and through the sum of $\mathrm{CO}_{2}$ fluxes obtained by EC (NEP) and soil chamber $\left(R_{\mathrm{h}}\right)$ methodology $\left(\mathrm{NPP}_{\text {flux }}\right)$. The seasonal trends, as well as the yearly cumulated values, are very close to each other, supporting the reliability of the employed methodological approach.

Since no direct measurements of $R_{\mathrm{a}}$ were carried out, a multiple approach was applied to assess it. As shown in Table $6, R_{\mathrm{a}}$ was estimated by (i) coupling $\mathrm{EC}$ with biometric measurements (GPP-NPP), (ii) coupling EC with soil chamber measurements $\left(R_{\mathrm{eco}}-R_{\mathrm{h}}\right)$ and (iii) coupling soil chambers measurements and biomass nitrogen determination. The difference between the results of the latter method and the previous two highlights the most important discrepancy we 
registered in the present study, which is due to the relatively higher amount of $\mathrm{C}$ fluxes obtained via soil chambers with respect to the EC-derived $R_{\text {eco }}$.

Mismatches between respiratory fluxes measured with different approaches are frequently reported in the literature (Ryan et al., 1997; Lavigne et al., 1997; Law et al., 1999). They are possibly due to selective systematic errors that easily occur at night by using the eddy covariance technique (Baldocchi, 2003; Aubinet, 2008), and also to random errors (Richardson et al., 2006), which may lead to uncertainties in the yearly NEE estimate, as well as the derived $R_{\text {eco }}$ and GPP. Additional reasons for observed inconsistencies between different measurement systems include chamber measurement accuracy, the mismatch of flux footprint, the underrepresentativeness of the point chosen for the measurements and the modeling of the missing data (Janssens et al., 2003)

We tried several methodologies for the gap-filling and flux partitioning procedure of our dataset, ranging from marginal distribution sampling (Reichstein et al., 2005) to light response curve (Lasslop et al., 2010), and to LUT (Moffat et al., 2007; Rossini et al., 2010 and present study), and we used the results from methodologies different from EC to assess the uncertainty in C flux estimates. Since the yearly amount of $R_{\mathrm{S}}$ measured by our multiplexed system was consistent with other published data (Blanke et al., 1995; Koerber et al., 2009; Ceccon et al., 2011) and we are quite confident about the results derived from biometric measurements $\left(\mathrm{NPP}_{\text {biom }}\right)$, LUT was the methodology which gave the most reliable estimate of EC-derived GPP and $R_{\text {eco. }}$. We chose it as the reference method, using the estimates from other methods to assess flux uncertainty.

The third method to assess $R_{\mathrm{a}}$ allowed us to obtain a second estimate of yearly GPP (GPP $\left.{ }_{\mathrm{BS}}\right)$ completely independent of eddy covariance measurements. This yielded higher figures with respect to $\mathrm{GPP}_{\mathrm{EC}}$ by approximately $250 \mathrm{~g} \mathrm{C} \mathrm{m}^{-2} \mathrm{yr}^{-1}$, suggesting an underestimation of $\mathrm{C}$ fluxes with EC.

\subsection{Annual and seasonal CUE}

The hypothesis that CUE is constant among forests (Gifford, 1994, 2003; Dewar et al., 1998; Ryan et al., 1997), with a possible appropriate universal value of 0.47 (Waring et al., 1998), was rejected by De Lucia et al. (2007), who reported a systematic large variation of CUE among forest types (from 0.23 to 0.83 ) over a wide range of published data. Amthor (2000) suggested a theoretical possible interval of CUE between 0.2 and 0.65 , confirmed also by experimental results on herbaceous species by van Iersel (2003), with crops generally having a higher value with respect to "natural" vegetation (Amthor, 1989). More recently, Van Oijen et al. (2010) proposed a theoretical approach, based on the law of mass conservation, to analyze the quantitative relationships between photosynthesis, respiration, growth and carbon storage in vegetation, suggesting a narrowly constrained respi- ration to photosynthesis ratio. Vicca et al. (2012) observed a significant spread in CUE values among different ecosystems, suggesting the nutritional status, and the consequent reduced allocation of photosynthates to symbionts, as the main driver for the variation found. The high CUE value found in this agro-ecosystem $(0.71 \pm 0.09)$ can be explained by a relatively low level of plant respiration $\left(R_{\mathrm{a}}\right)$, by a lower amount of photosynthates allocated to the non-biomass component of NPP, or both.

A possible explanation for a relatively low $R_{\mathrm{a}}$ level may be found in both structural characteristics of the orchard and climatic conditions of the site. Regarding the first aspect, despite the fact that our understanding of plant $R_{\mathrm{a}}$ is still incomplete and poorly parameterized in current models (Piao et al., 2010), several studies (Ryan et al., 1997; Arneth et al., 1998; Law et al., 1999) highlighted the importance of the biomass composition in determining the total $R_{\mathrm{a}}$, with foliage respiration having the greatest incidence on total $R_{\mathrm{a}}$ when considered over unit of biomass. In our apple orchard, leaves represent only $11 \%$ of total NPP with respect to the average value of $30 \%$ for deciduous forests $(n=32)$ calculated from the database of Luyssaert et al. (2007). Crops, on the contrary, allocate most of the $\mathrm{C}$ in storage organs such as seeds and tubers, which have a relatively small growth respiration and a generally low maintenance respiration (Amthor, 2000). In our case, $52 \%$ of NPP was represented by fruit. Apple fruit have a specific cost for synthesis and maintenance of approximately $1.15 \mathrm{gglucose}^{-1}$, significantly lower of that of apple leaves $\left(1.44 \mathrm{~g} g l u c o s e^{-1}\right)$ and wood

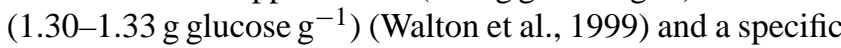
dark respiration that rapidly declines as growth by cell expansion begins (Jones, 1981; Bepete and Lakso, 1997). Moreover, the yearly pruning of apple trees favors the exposition of apple leaves to direct light, thus enhancing their potential photosynthetic capacity. Our findings confirm the hypothesis that apple trees have relatively low autotrophic respiration rates compared to many other plants due to the low construction costs of fruit (Lakso et al., 1999). The fact that apple trees grafted on dwarfing rootstocks, like in our study orchard, have a relatively small tree framework and root system likely contributes to explaining the high value of CUE. Additionally, the low nitrogen content of apple fruit $(0.29 \%)$ associated with their elevated incidence on total plant biomass $(33 \pm 7 \%)$ are in line with Reich et al. (2006; see also Ryan et al., 1996), who observed an almost linear correlation between total plant nitrogen and total plant respiration.

Climatic conditions may also contribute to explaining the high CUE observed: following findings of Piao et al. (2010) over a wide range of ecosystems, and the related debate (Enquist, 2011; Chen et al., 2011), it emerges a possible role of the mean annual temperature (MAT) in controlling the $R_{\mathrm{a}}$ to GPP ratio, and the MAT of our site $\left(11.5^{\circ} \mathrm{C}\right)$ is very close to the indicated one $\left(\sim 11.0^{\circ} \mathrm{C}\right)$ at which this ratio reaches its minimum at global scale. In addition, optimal conditions 
of water availability prevent CUE drop due to drought (Metcalfe et al., 2011; Panzacchi et al., 2012).

The ratio between biomass production and GPP observed in the studied orchard is well above the regression line found in Vicca et al. (2012) even for the most fertile forest ecosystems. This suggests that multiple factors enhancing CUE have to be considered, including climate and plant physiological traits as well as management activities such as irrigation, fertilization and pruning.

This study helped assess the seasonal trend of CUE, using both $\mathrm{NPP}_{\text {biom }}$ and $\mathrm{NPP}_{\text {flux }}$ over the same GPP $\mathrm{EC}_{\mathrm{EC}}$ values. According to Campioli et al. (2011), it is important to specify that the variability of GPP estimates over a short period, depending on the selected partitioning method, may have a great effect on the CUE value, thus making it difficult to speculate on the absolute values observed along the season in each estimate, which in our case was occasionally above the unit. As shown in Fig. 8, the greatest discrepancy between the two curves of $\mathrm{CUE}_{\text {biom }}$ and $\mathrm{CUE}_{\text {flux }}$ occurs in spring, particularly in the first two months after budburst, where $\mathrm{NPP}_{\text {biom }}$ estimate was greater than $\mathrm{NPP}_{\text {flux }}$ and in the autumn, when the opposite was observed. Although the variation of carbon reserves along the year in mobile forms such as starch was not measured, we interpreted these results as a clear sign of remobilization (Mauler et al., 2004; Millard et al., 2007), with apple trees using stored carbohydrates in the first two months after budburst and likely reallocating $\mathrm{C}$ to storage organs after harvest. Although a spring peak of CUE followed by a quick decline after May was observed by Campioli et al. (2011) in a temperate beech forest, in our case the NPP : GPP ratio was high also throughout the summer, mainly due to the continued biomass accumulation in fruit. This suggests a lower accumulation of nonstructural soluble carbohydrates with respect to what is occurring in forests (Hoch et al., 2003).

\section{Conclusions}

This study demonstrates that the main ecosystem carbon fluxes of an $11 \mathrm{yr}$ old apple orchard have a comparable magnitude with respect to deciduous forests growing in similar climate conditions. The major differences were a higher NPP in the apple orchard and a different allocation pattern of fixed $\mathrm{C}$, with fruit representing approximately half of total yearly NPP. CUE, obtained from four methods, was $0.71 \pm 0.12$, indicating an elevated capacity of the orchard to allocate photosynthates to biomass production. The high amount of fruit biomass may be a possible explanatory reason for the high CUE found in the present study because of both the reported low respiratory costs for producing the simple sugars present in fruit and their low nitrogen content. The environmental conditions present in the orchards, obtained by pruning and supplying water and nutrients to the soil, represent another explanation for the high CUE, possibly limiting the transfer of photosynthates to non-biomass components of NPP, such as root exudates.

Given the high amount of carbon allocated to apple fruit, mostly exported from the ecosystem every year, and the limited amount of $\mathrm{C}$ that increases the standing biomass of apple trees, the role of the apple orchard to act as a sink of carbon to the atmosphere largely depends on the persistence of the fraction of $\mathrm{C}$ that annually feeds the detritus cycle.

This work suggests that in global biogeochemical modeling, it has to be considered that the CUE of agro-ecosystems can be higher than that of forests growing in a similar climate. Further research is needed to establish whether the high CUE observed is a common feature of agricultural systems.

Acknowledgements. This project was carried out with financial support from Autonomous Province Bolzano-Bozen project "Assessing the potential for $\mathrm{CO}_{2}$ sequestration by apple orchards in South Tyrol" and from the Minister of University Prin 2008 project prot. 2008LX3AYP_001 "Carbon fluxes in the apple orchard".

The authors wish to thank for their assistance and valuable support Christian Ceccon, Francesca Scandellari, Tanja Mimmo and Maddalena Bolognesi (Free University of Bolzano-Bozen) George Wellington Bastos de Melo (Embrapa Uva e Vinho, Brasil), Paulo Cassol (Santa Catarina State University, Brasil), Martin Thalheimer (Research Centre for Agriculture and Forestry, Laimburg, BZ) and Robert Sinn (owner of the experimental site). We wish to thank also the three anonymous reviewers for their thorough, constructive comments.

Edited by: P. Stoy

\section{References}

Akburak, S., Oral, H. V., Ozdemir, E., and Makineci, E.: Temporal variation of biomass, carbon and nitrogen of roots under different tree species, Scand. J. Forest Res., 28, 8-16, doi::10.1080/02827581.2012.679680, 2012.

Amthor, J. S.: Respiration and crop productivity, New York, Springer Verlag, 1989.

Amthor, J. S.: The Mc Cree-de Wit-Penning de Vries-Thornley respiration paradigms: 30 Years Later, Ann. Bot.-London, 86, 1-20, 2000.

Arneth, A., Kelliher, F. M., McSeveny, T. M., and Byers, J. M.: Net ecosystem productivity, net primary productivity and ecosystem carbon sequestration in a Pinus radiata plantation subject to soil water deficit, Tree Physiol., 18, 785-793, 1998.

Arneth, A., Schurgers, G., Lathiere, J., Duhl, T., Beerling, D. J., Hewitt, C. N., Martin, M., and Guenther, A.: Global terrestrial isoprene emission models: sensitivity to variability in climate and vegetation, Atmos. Chem. Phys., 11, 8037-8052, doi:10.5194/acp-11-8037-2011, 2011.

Aubinet, M.: Eddy covariance $\mathrm{CO}_{2}$ flux measurements in nocturnal conditions: an analysis of the problem. Ecol. Appl., 18, 13681378, 2008.

Aubinet, M., Grelle A., Ibrom, A., Rannik, Ü., Moncrieff, J. B., Foken, T., Kowalski, A.S., Martin, P. H., Berbigier, P., Bernhofer, 
C., Clement, R., Elbers, J., Granier, A., Grünwald, T., Morgenstern, K., Pilegaard, K., Rebmann, C., Snijders, W., Valentini, R., and Vesala, T.: Estimates of the annual net carbon and water exchange of forests: The EUROFLUX methodology, Adv. Ecol. Res., 30, 113-175, 2000.

Baldocchi, D. D.: Assessing the eddy covariance technique for evaluating carbon dioxide exchange rates of ecosystems: past, present and future, Glob. Change Biol., 9, 479-492, 2003.

Baldocchi, D. D.: "Breathing" of the terrestrial biosphere: Lessons learned from a global network of carbon dioxide flux measurement systems, Aust. J. Bot., 56, 1-26, 2008.

Beer, C., Reichstein, M., Tomelleri, E., Ciais, P., Jung, M., Carvalhais, N., Rödenbeck, C., Arain, M. A., Baldocchi, D., Bonan, G.B., Bondeau, A., Cescatti, A., Lasslop, G., Lindroth, A., Lomas, M., Luyssaert, S., Margolis, H., Oleson, K.W., Roupsard, O., Veenendaal, E., Viovy, N., Williams, C., Woodward, F., and Papale, D.: Terrestrial gross carbon dioxide uptake: Global distribution and covariation with climate, Science, 329, 834-838, 2010.

Bepete, M. and Lakso, A. N.: Apple fruit respiration in the field: Relationship to fruit growth rate, temperature and light exposure, Acta Hortic., 451, 319-326, 1997.

Blanke, M. M.: Soil respiration in an apple orchard, Environ. Exp. Bot., 36, 339-348, 1995.

Bowden, R. D., Nadelhoffer, K. J., Boone, R. D., Melillo, J. M., and Garrison, J. B.: Contribution of aboveground litter, belowground litter, and root respiration to total soil respiration in a temperature mixed hardwood forest, Can. J. Forest Res., 23, 1402-1407, 1993.

Campioli, M., Gielen, B., Göckede, M., Papale, D., Bouriaud, O., and Granier, A.: Temporal variability of the NPP-GPP ratio at seasonal and interannual time scales in a temperate beech forest, Biogeosciences, 8, 2481-2492, doi:10.5194/bg-8-24812011, 2011.

Canadell, J. G., Le Quéré, C., Raupach, M. R., Field, C. B., Buitenhuis, E. T., Ciais, P., Conway, T. J., Gillett, N. P., Hougton, R. A., and Marland, G.: Contributions to accelerating $\mathrm{CO}_{2}$ growth from economic activity, carbon intensity and efficiency of natural sinks, P. Natl. Acad. Sci. USA, 104, 18866-18870, 2007.

Cannell, M. G. R. and Dewar, R. C.: Carbon Allocation in Trees: a Review of Concepts for Modelling, Adv. Ecol. Res., 25, 59-104, 1994.

Ceccon, C., Panzacchi, P., Scandellari, F., Prandi, L., Ventura, M., Russo, B., Millard, P., and Tagliavini, M.: Spatial and temporal effects of soil temperature and moisture and the relation to fine root density on root and soil respiration in a mature apple orchard, Plant Soil, 342, 195-206, 2011.

Chalmers, D. J. and van den Ende, B.: Productivity of Peach Trees: Factors Affecting Dry-weight Distribution During Tree Growth, Ann. Bot.-London, 39, 423-432, 1975.

Chen, A., Piao, S., Luyssaert, S., Ciais, P., Janssen, I. A., Friedlingstein, P., and Luo, Y.: Forest annual carbon cost: reply, Ecology, 92, 1998-2002, 2011.

Cheng, W. and Gershenson, A.: Carbon fluxes in the rhizosphere, The Rhizosphere, An ecological perspective, chapter 2 , 29-54, 2007.

Ciais, P., Wattenbach, M., Vuichard, N., Smith, P., Piao, S. L., Don, A., Luyssaert, S., Janssens, I. A., Bondeau, A., Dechow, R., Leip, A., Smith, P.C., Beer, C., van den Werf, S., Gervois, S., van Oost,
K., Tomelleri, E., Freibauer, A., and Schulze, E. D.: The European carbon balance. Part 2: croplands. Glob. Change Biol., 16, 1409-1428, 2010.

Clark, D. A., Brown, S., Kicklighter, D. W., Chambers, J. Q., Thomlinson, J. R., and Jian, N.: Measuring net primary production in forests: Concepts and field methods, Ecol. Appl., 11, 356-370, 2001.

Curtis, P. S., Hanson, P. J., Bolstad, P., Barford, C., Randolph, J. C., Schmid, H. P., and Wilson, K. B.: Biometric and eddy-covariance based estimates of annual carbon storage in five eastern North American deciduous forests, Agr. Forest Meteorol., 113, 3-19, 2002.

De Lucia, E., Drake, J. E., Thomas, R. B., and Melers, M. G.: Forest carbon use efficiency: is respiration a constant fraction of gross primary production?, Glob. Change Biol., 13, 1157-1167, 2007.

Dewar, R. C., Medlyn, B. E., and McMurtrie R. E.: A mechanistic analysis of light and carbon use efficiencies, Plant Cell Environ., 21, 573-588, 1998.

Dìaz-Pìnes, E., Schindlbacher, A., Pfeffer, M., Jandl, R., Boltenstern, S. Z., and Rubio, A.: Root trenching: a useful tool to estimate autotrophic soil respiration? A case study in an Austrian mountain forest, Eur. J. For. Res., 129, 101-109, 2010.

Eissenstat, D. M., Bauerle, T. L., Comas, L. H., Lakso, A. N., Neilsen, D., Neilsen, G. H., and Smart, D. R.: Seasonal patterns of root growth in relation to shoot phenology in grape and apple, Acta Hortic., 721, 21-26, 2006.

Enquist, B. J.: Forest annual carbon cost: comment, Ecology, 92, 1994-1998, 2011.

Eugster, W. and Senn, W.: A cospectral correction model for measurement of turbulent $\mathrm{NO}_{2}$ flux, Bound. Layer Meteorol., 74, 321-340, 1995.

Fahey, T. J., Huges, J. W., Pu, M., and Arthur, M. A.: Root decomposition and nutrient flux following whole-tree harvest of northern hardwood forest, Forest Sci., 34, 744-768, 1988.

FAOSTAT: Statistical Databases. Agriculture Data Collection (Primary Crops), FAO Food and Agriculture Organization of the United Nations, Rome, http://faostat.fao.org/site/567/ DesktopDefault.aspx?PageID $=567$ \#ancor, data referring to the year 2010, retrieved in March 2013.

Faqi, W., Haibin, L., Baosheng, S., Jian, W., and Gale, W. J.: Net primary production and nutrient cycling in and apple orchard annual crop system in the Loess Plateau, China: a comparison of Quinguan apple, Fuji apple corn and millet production subsystems, Nutr. Cycl. Agroecosys., 81, 95-105, 2008.

Farrar, J., Haves, M., Jones, D. L., and Lindow, S.: How roots control the flow of carbon to the rhizosphere, Ecology, 84, 827-837, 2003.

Foken, T. and Wichura B.: Tools for quality assessment of surfacebased flux measurements, Agr. For. Meteorol., 78, 83-105, 1996.

Gifford, R. M.: The global carbon cycle: a viewpoint on the missing sink. Aust, J. Plant Physiol., 21, 1-15, 1994.

Gifford, R. M.: Plant respiration in productivity models: conceptualization, representation and issues for global terrestrial carboncycle research, Funct. Plant Biol., 30, 171-186, 2003.

Giuliani, R., Nerozzi F., Magnanini, E., and Corelli-Grappadelli, L.: Influence of environmental and plant factors on canopy photosynthesis and transpiration of apple trees, Tree Physiol., 17, 637645, 1997. 
Grayston, S. J., Vaughan, D., and Jones, D.: Rhizosphere carbon flow in trees, in comparison with annual plants: the importance of root exudation and its impact on microbial activity and nutrient availability, Appl. Soil Ecol., 5, 29-56, 1997.

Hanson, P. J., Edwards, N. T., Garten, C. T., and Andrews, J. A.: Separating root and microbial contribution to soil respiration, A review of methods and observations, Biogeochemestry, 48, 115146, 2000.

Hoch, G., Richter, A., and Körner, C.: Non-structural carbon compounds in temperate forests trees, Plant Cell Environ., 26, 10671081, 2003.

Intergovernmental Panel on Climate Change: AR-4, Climate Change, Synthesis Report, Contribution of Working Groups I, II and III to the Fourth Assessment Report of the Intergovernmental Panel on Climate Change, IPCC, Geneva, Switzerland, 104 pp., 2007.

Janssens, I. A., Dore, S., Epron, D., Lankreijer, H., Buchmann, N., Longdoz, B., Brossaud, J., and Montagnani, L.: Climatic influences on seasonal and spatial differences in soil $\mathrm{CO}_{2}$ efflux, in: Canopy fluxes of energy, water and carbon dioxide of European forests, edited by: Valentini, R., Berlin, Ecological Studies, Springer, 235-256, 2003.

Jones, D. L., Hodge, A., and Kuzyakov, Y.: Plant and mycorrhizal regulation of rhizodeposition, New Phytol., 163, 459-480, 2004.

Jones, D. L., Nguyen, C., and Finlay, R. D.: Carbon flow in the rhizosphere: carbon trading at the soil-root interface, Plant Soil, 321, 5-33, 2009.

Jones, H. G.: Carbon Dioxide Exchange of Developing Apple (Malus pumila Mill.) Fruits, J. Exp. Bot., 32, 1203-1210, 1981.

Koerber, G. R., Jones, G. E., Hill, P. W., Canals, L. M., Nyeko, P., York, E. H., and Jones, D. L.: Geographical variantion in carbon dioxide fluxes from soils in agro-ecosystems and its implication for life cycle assessment, J. Appl. Ecol., 46, 306-314, 2009.

Kolle, O. and Rebmann, C.: Eddysoft - Documentation of a Software Package to Acquire and Process Eddy Covariance Data, Technical Reports, p. 88, Max-Planck Institut für Biogeochemie, Jena, Germany, 2007.

Kuzyakov, Y., Friedel, J. K., and Stahr, K.: Review of mechanisms and quantification of priming effects, Soil Biol. Biochem., 32, 1485-1498, 2000.

Lakso, A. N., Wünshe, J. N., Palmer, J. W., and Grappadelli L. C.: Measurement and modeling of carbon balance of the apple tree, Hortic. Sci., 34, 1040-1047, 1999.

Lambert, B. B., Bronson, D., Bladyka, E., and Gower, S. T.: A comparison of trenched plots techniques for partitioning soil respiration, Soil Biol. Biochem., 43, 2108-2114, 2011.

Lasslop, G., Reichstein, M., Papale, D., Richardson, A.D., Arneth, A., Barr, A., Stoy, P., and Wohlfahrt, G.: Separation of net ecosystem exchange into assimilation and respiration using a light response curve approach: critical issue and global evaluation, Glob. Change Biol., 16, 187-208, 2010.

Lavigne, M. B., Ryan, M. G., Anderson, D. E., Baldocchi, D. D., Crill, P. M., Fitzjarrald, D. R., Goulden, M. L., Gower, S. T., Massheder, J. M., McCauhey, J. H., Rayment, M., and Striegl, R. G.: Comparing nocturnal eddy covariance measurements to estimates of ecosystem respiration made by scaling chamber measurements, J. Geophys. Res., 102, 28977-28986, 1997.

Law, B. E., Ryan, M. G., and Anthoni, P. M.: Seasonal and annual respiration of ponderosa pine ecosystem, Glob. Change Biol., 5,
169-182, 1999.

Law, B. E., Arkebauer, T., Campbell, J. L., Chen, J., Sun, O., Schwartz, M., van Ingen, C., and Verma, S.: Terrestrial Carbon Observations: Protocols for Vegetation Sampling and Data Submission. Report 55, Global Terrestrial Observing System. FAO, Rome. 87 pp., 2008.

Le Quèrè, C., Raupach, M. R., Canadell, J. G., Marland, G., Bopp, L., Ciais, P., Conway, T., Doney, S. C., Feely, R. A., Foster, P., Friedlingstein, P., Gurney, K., Houghton, R.A., House, J.I., Huntingford, C., Levy, P. E., Lomas, M. R., Majkut, J., Metzl, N., Ometto, J. P., Peters, G. P., Prentice, I. C., Randerson, J. T., Running, S. W., Sarmiento, J. L., Schuster, U., Sitch, S., Takahashi, T., Viovy, N., van der Werf, G. R., and Woodward, F. I.: Trends in the sources and sinks of carbon dioxide, Nat. Geosci., 2, 831836, doi:10.1038/NGEO689, 2009.

Liguori, G., Gugliuzza, G., and Inglese, P.: Evaluating carbon fluxes in orange orchards in relation to planting density, J. Agr. Sci., 147, 637-645, 2009.

Lloyd, J. and Taylor, J. A.: On the temperature dependence of soil respiration, Funct. Ecol., 8, 315-323, 1994.

Loescher, H. W., Law, B. E., Mahrt, L. Hollinger, D. Y. Campbell, J., and Wofsy, S. C: Uncertainties in, and interpretation of, carbon flux estimates using the eddy covariance technique, J. Geophys. Res., 111, D21S90, doi:10.1029/2005JD006932, 2006.

Luyssaert, S., Inglima, I., Jung, M., Richardson, A.D., Reichstein, M., Papale, D., Piao, S. L., Schulze, E.D., Wingate, L., Matteucci, G., Aragao, L., Aubinet, M., Beer, C., Bernhofer C., Black, K. G., Bonal, D., Bonnefond, J.M., Chambers J., Ciais, P., Cook, P., Davis, K. J., Dolman A. J., Gielen, B., Goulden, M., Grace, M., Granier, A., Grelle, A., Griffis T., Grünwald, T., Guidolotti, G., Hanson P. J., Harding, R., Hollinger, D. Y., Hutyra, L.R., Kolari P., Kruijt, B., Kutsch, W., Lagergren F., Laurila, T., Law, B. E., Le Maire, G., Lindroth A., Loustau D., Malhi, Y., Mateus, J., Migliavacca, M., Misson, L., Montagnani, L., Moncrieff, J., Moors J., Munger J.W., Nikinmaa, E., Ollinger, S. V., Pita, G., Rebmann, C., Roupsard, O., Saigusa, N., Sanz, M. J., Seufert, G., Sierra, C., Smith, M. L., Tang, J., Valentini, R., Vesala, T., and Janssens, I.A.: $\mathrm{CO}_{2}$ balance of boreal, temperate, and tropical forests derived from a global database, Glob. Change Biol., 13, 1-29, 2007.

Luyssaert, S., Schulze, E.D., Börner, A., Knohl, A., Hessenmöller, D., Law, B. E., Ciais, P., and Grace., J.: Old-growth forests as global carbon sinks, Nature, 455, 213-215, 2008.

Malhi, Y., Aragão, L. E. O. C., Metcalfe, D. B., Paiva, R., Quesada, C. A., Almeida, S., Anderson, L., Brando, P., Chambers, J. Q., da Costa, J. C. L., Hutyra, L. R., Oliveira, P., Patino, S., Pyle, E. H., Robertson, A. L., and Teixeira, L. M.: Comprehensive assessment of carbon productivity, allocation and storage in three Amazonian forests, Glob. Change Biol., 15, 1255-1274, 2009.

Mauder, M., Foken, T., Clement, R., Elbers, J. A., Eugster, W., Grünwald, T., Heusinkveld, B., and Kolle, O.: Quality control of CarboEurope flux data - Part 2: Inter-comparison of eddy-covariance software, Biogeosciences, 5, 451-462, doi:10.5194/bg-5-451-2008, 2008.

Maurel, K., Leite, G. B., Bonhomme, M., Guilliot, A., Rageau, R., Pétel, G., and Sakr, S.: Trophic control of bub break in peach (Prunus persica) trees: a possible role of hexoses, Tree Physiol., 24, 579-588, 2004. 
Metcalfe, D. B., Meir, P., Aragao, L. E. O. C., Lobo-do-Vale, R., Galbraith, D., Fisher, R. A., Chaves, M. M., Maroco, J. P., da Costa, A. C. L., de Almeida, S. S., Braga, A. P., Gonçalves, P. H. L., de Athaydes, J., da Costa, M., Portela, T. T. B., de Oliveira, A. A. R., Malhi, Y., and William, M.: Shifts in plant respiration and carbon use efficiency at a large-scale drought experiment in the eastern Amazon, New Phytol. 187, 608-621, 2011.

Millard, P., Sommerkorn, M., and Grelet, G.: Environmental change and carbon limitation in trees: a biochemical, ecophysiological and acosystem appraisal, New Phytol., 175, 11-28, 2007.

Minchin, P. E. H., Thorpe, M. R., Wünshe, J. N., Palmer, J. W., and Picton, R. F.: Carbon partitioning between apple fruits: short- and long-term response to availability of photosynthate, J. Exp. Bot., 48, 1401-1406, 1997.

Moffat, A. M., Papale, D., Reichstein, M., Hollinger, D. Y., Richardson, A. D., Barr, A. G., Beckstein, C., Braswell, B. H., Churkina, G., Desai, A. R. Falge, E., Gove, J. H., Heimann, M., Hui, D., Jarvis, A. J., Kattge, J., Noormets, A., and Stauch V. J.: Comprehensive comparison of gap-filling techniques for eddy covariance net carbon fluxes, Agr. For. Meteorol., 147, 209-232, 2007.

Navarro, M. N. V., Jourdan, C., Sileye, T., Braconnier, S., MialetSerra, I., Saint-Andre, L., Dauzat, J., Nouvellon, Y., Epron, D., Bonnefond, J.M., Berbigier, P., Rouziere, A., Bouillet, J. P., and Roupsard, O.: Fruit development, not GPP, drives seasonal variation in NPP in a tropical palm plantation, Tree Physiol., 28, 1661-1674, 2008.

Osborne, B., Saunders, M, Walmsley, D., Jones, M., and Smith, P.: Key questions and uncertainties associated with the assessment of the cropland greenhouse gas balance, Agr. Ecosyst. Environ., 139-3, 293-301, 2010.

Palmer, J. W.: Annual dry matter production and partitioning over the first 5 years of a bed system of Crispin-M27 apple trees at four spacings, J. Appl. Ecol., 25, 569-578, 1988.

Panzacchi, P., Tonon, G., Ceccon, C., Scandellari, F., Ventura, M., Zibordi, M., and Tagliavini, M.: Belowground carbon allocation and net primary and ecosystem productivities in apple trees (Malus domestica) as affected by soil water availability, Plant Soil, 360, 229-241, doi:10.1007/s11104-012-1235-2, 2012.

Peng, Y., Gitelson, A. A., and Sakamoto, T.: Remote estimation of gross primary productivity in crops using MODIS $250 \mathrm{~m}$ data, Remote Sens. Environ., 128, 186-196, 2013.

Peters, G. P., Marland, G., Le Quéré, C., Boden, T., Canadell, J. G., and Raupach, M. R.: Rapid growth of $\mathrm{CO}_{2}$ emission after the 2008-2009 global financial crisis, Nature Climate Change, 2, $1-3,2011$

Piao, S., Luyssaert, S., Ciais, P., Janssen, I. A., Chen, A., Cao, C., Fang, J., Friedlingstein, P., Luo, Y., and Wang, S.: Forest annual carbon cost: a global scale analysis of autotrophic respiration, Ecology, 91, 652-661, 2010.

R Development Core Team: R: A language and environment for statistical computing, R Foundation for Statistical Computing, Vienna, Austria, ISBN 3-900051-07-0, http://www.R-project.org, 2008.

Rachpal, S. J. and Black, T. A.: Estimating heterotrophic and autotrophic soil respiration using small area trenching plot technique: Theory and Practice, Agr. For. Meteorol., 140, 193-202, 2006.

Rayment, M. B., Lousau, D., and Jarvis, P. G.: Photosynthesis and respiration of black spruce at three organizational scales: shoot, branch and canopy, Tree Physiol., 22, 219-229, 2002.

Reganold, J. P., Glover, J. D., Andrews, P. K., and Hinman, H. R.: Sustainability of tree apple production systems, Nature, 410, 926-930, 2001.

Reich, P. B., Tjoelker, M. G., Machado, J.L., and Oleksyn J.: Universal scaling of respiratory metabolism, size and nitrogen in plants, Nature, 439, 457-461, 2006.

Reichstein, M., Falge, E., Baldocchi, D., Papale, D., Aubinet, M., Berbigier, P., Bernhofer, C., Buchmann, N., Gilmanov, T., Granier, A., Grünwald, T., Havrankova, K., Ilvesmiemi, H., Janous, D., Knohl, A., Laurila, T., Lohila, A., Loustau, D., Matteucci, G., Meyers, T., Miglietta, F., Ourcival, J. M., Pumpanen, J., Rambal, S., Rotemberg, E., Sanz, M., Tenhunen, J., Seufert, G., Vaccari, F., Vesala, T., Yakir, D., and Valentini, R.: On the separation of net ecosystem exchange into assimilation and ecosystem respiration: review and improved algorithm, Glob. Change Biol., 11, 1424-1439, 2005.

Richardson, A. D., Hollinger, D. Y., Burba, G. G., Davis, K. J., Flanagan, L. B., Katul, G. G., Munger, J. W., Ricciuto, D. M., Stoy, P. C., Suyker, A. E., Verma, S. B., and Wosfy, S. C.: A multi-site analysis of random error in tower-based measurements of carbon and energy fluxes, Agr. For. Meteorol., 136, 1-18, 2006.

Rossi, F., Facini, O., Georgiadis, T., and Nardino, M.: Seasonal $\mathrm{CO}_{2}$ fluxes and energy balance in a kiwifruit orchard, Italian Journal of Agrometeorology, 2007, 44-56, 2007.

Rossini, M., Meroni, M., Migliavacca, M., Manca, G., Cogliati, G., Busetto, L., Picchi, V., Cescatti, A., Seufert, G., and Colombo, R.: High resolution field spectroscopy measurements for estimating gross ecosystem production in a rice field, Agr. For. Meteorol., 150, 1283-1296, 2010.

Ryan, M. G., Hubbard, R. M., Pongracic, S., Raison, R. J., and McMutrie, R. E.: Foliage, fine-root, woody tissue and stand respiration in Pinus radiata in relation to nitrogen status, Tree Physiol., 16, 333-343, 1996.

Ryan, M. G., Lavigne, M. B., and Gower, S. T.: Annual carbon cost of boreal forest ecosystem in relation to species and climate, J. Geophys. Res., 102, 28871-28883, 1997.

Savage, K., Davidson, E. A., and Richardson, A. D.: Belowground responses to climate change. A conceptual and practical approach to data quality and analysis procedures for highfrequency soil respiration measurements, Funct. Ecol., 22, 10001007, 2008.

Scandellari, F., Tonon, G., Thalheimer, M., Ceccon, C., Gioacchini, P., Aber, J. D., and Tagliavini, M.: Assessing nitrogen fluxes from roots to soil associated to rhizodeposition by apple (Malus domestica) trees, Trees, 21, 499-505, 2007.

Schimel, D. S., House, J. I., Hibbard, K. A., Bousquet, B., Ciais, P., Peylin, P., Braswell, B. H., Apps, M.J., Baker, D., Bondeau, A., Canadell, J., Churkina, G., Cramer, W., Denning, A. S., Field, C. B., Friedlingstein, P. G., Goodale, C., Heimann, M., Houghton, R. A., Melillo, J. M., Moore III, B., Murdiyarso, D., Noble, I., Pacala, S. W., Prentice, I. C., Raupach, M. R., Rayner, P. J., Scholes, R. J., Steffen, W. L., and Wirth, C.: Recent pattern and mechanisms of carbon exchange by terrestrial ecosystems. Nature, 414, 169-172, 2001.

Schulze, E.-D.: Biological control of the terrestrial carbon sink, Biogeosciences, 3, 147-166, doi:10.5194/bg-3-147-2006, 2006. 
Schulze, E. D., Ciais, P., Luyssaert, S., Schrumpf, M., Janssens, I. A., Thiruchittampalam, B., Theloke, J., Saurat, M., Bringezu, S., Lelieveld, J., Lohila, A., Rebmann, C., Jung, M., Bastwiken, D., Abril, G., Grassi, G., Leip, A., Freibauer, A., Kutsch, W., Don, A., Nieschulze, J., Börner, A., Gasch, J. H., and Dolmann, A. J.: The European Carbon balance. Part 4: integration of carbon and other trace gas fluxes, Glob. Change Biol., 16, 1451-1469, 2010.

Smith, P.: Carbon sequestration in croplands: the potential in Europe and the global context, Eur. J. Agron., 20, 229-236, 2004.

Subke, J. R., Inglima, I., and Cotrufo, M. F.: Trends and methodological impacts of soil $\mathrm{CO}_{2}$ efflux partitioning: a metaanalytical review, Glob. Change Biol., 12, 921-943, 2006.

Tagliavini, M., Tonon, G., Scandellari, F., Quiñones, A., Palmieri, S., Menarbin, G., Gioacchini, P., and Masia, A.: Nutrient recycling during the decomposition of apple leaves (Malus domestica) and mowed grassed in an orchard, Agr. Ecosyst. Environ., 118, 191-200, 2007.

Tan, Z., Yiping, Z., Guirui, Y., Liqing, S., Jianwei, T., Xiaobao, D., and Qinghai, S.: The carbon balance of a primary tropical seasonal rain forest, J. Geophys. Res.-Atmos., 115, D00H26, doi:10.1029/2009JD012913, 2011.

Tartachnyk, I. I. and Blanke, M. M.: Effect of delayed fruit harvest on photosynthesis, transpiration and nutrient remobilization of apple leaves, New Phytol., 164, 441-450, 2004.

Taylor, J. R.: An Introduction to Error Analysis, The Study of Uncertainties in Physical Measurements, University Science Books, 1982.

Testi, L., Orgaz, F., and Villalobos F.: Carbon exchange and water use efficiency of a growing, irrigated olive orchard, Environ. Exp. Bot., 63, 168-177, 2008.
Van Iersel, M. W.: Carbon use efficiency depends on growth respiration, maintenance respiration and relative growth rate. A case study with lettuce, Plant Cell Environ., 26, 1441-1449, 2003.

Van Oijen, M., Shapendonk, A., and Höglind, M.: On the relative magnitudes of photosynthesis, respiration, growth and carbon storage in vegetation. Ann. Bot. London, 105, 793-797, 2010.

van't Hoff, J. H.: Etudes de dynamique chemique, Frederik Muller \& Co., Amsterdam, 1884

Ventura, M., Scandellari, F., Bonora, M., and Tagliavini, M.: Nutrient release during decomposition of leaf litter in a peach (Prunus persica L.) orchard, Nutr. Cycl. Agroecosys., 87, 115-125, 2009.

Vicca, S., Luyssaert, S., Peňuelas, J., Campioli, M., Chapin III, F.S., Ciais, P., Heinemeyer, A., Högberg, P., Kutsch, W. L., Law, B. E., Malhi, Y., Papale, D., Piao, S. L., Reichstein M., Schulze E. D., and Janssens I. A.: Fertile forests produce biomass more efficiently, Ecol. Lett., 15, 520-526, doi:10.1111/j.14610248.2012.01775.x, 2012.

Vickers, D., Thomas, C. K., Martin, J. G., and Law. B.: Selfcorrelation between assimilation and respiration resulting from flux partitioning of eddy covariance $\mathrm{CO}_{2}$ fluxes, Agr. For. Meteorol., 149, 1552-1555, 2009.

Walton, E. F., Wünsche, J. N., and Palmer, J. W.: Estimation of the bioenergetic costs of fruit and other organ synthesis in apple, Physiol. Plantarum, 106, 129-134, 1999.

Waring, R. H., Landsberg, J. J., and Williams, M.: Net primary production of forests: a constant fraction of gross primary production?, Tree Physiol., 18, 129-134, 1998.

Wells, C. E. and Eissenstat, D. M.: Marked differences in survivorship among apple roots of different diameters, Ecology, 82, 882892, 2001. 